\title{
Western Australian Onychophora (Peripatopsidae): a new genus, Kumbadjena, for a southern species-complex
}

\author{
Amanda Reid \\ 6 Sturt Place, Bulli, New South Wales, 2516, Australia. Email: mandy.reid@optusnet.com.au
}

\begin{abstract}
Two species of Onychophora (Peripatopsidae) were previously known to occur in the south-western corner of Western Australia: Occiperipatoides occidentalis (Fletcher, 1895) and Occiperipatoides gilesii (Spencer, 1909). These two taxa occupy geographically disjunct regions. Using morphological characters, Occiperipatoides 'occidentalis' is shown to comprise a species-complex; three species are described here, two of which are new. A new genus, Kumbadjena, is erected for $O$. 'occidentalis' to reflect the significant morphological and molecular differences between members of this complex and $O$. gilesii. The Kumbadjena gen. nov. group occupies a region of relatively high rainfall in the southernmost portion of the state, its distribution reflecting that of karri Eucalyptus diversicolor (Mueller). The monotypic Occiperipatoides gilesii is found in the area surrounding Perth on the Swan Coastal Plain and along the scarp and western parts of the Darling Range plateau. The distribution of these two taxa is discussed in relation to past geographical events.
\end{abstract}

\section{INTRODUCTION}

The present study was prompted by the discovery of considerable variation among specimens previously assigned to Occiperipatoides occidentalis (Fletcher, 1985) (Reid, 1996). In addition, the number of pronounced morphological differences distinguishing O. occidentalis and O. gilseii (Spencer, 1909 ) and the documentation of $81 \%$ fixed gene difference between representatives of these two taxa (Briscoe and Tait, 1995), suggested that generic separation was justified (Reid, 1996). An impediment to addressing both of these issues was the lack of sufficient numbers of well-preserved specimens from a number of populations of $O$. occidentalis and the absence of O. occidentalis type material for comparison: the type specimens are believed lost.

In addition to collections made in recent times by members of the Western Australian Museum, the collection of new material undertaken by the author in 1995 and 2000 has enabled some of these difficulties to be overcome, but has also introduced some new ones.

However, detailed comparison of these new, and previously collected museum specimens strongly supports the separation of the Western Australian onychophoran fauna into two genera. A new genus, Kumbadjena gen. nov. is erected here for species belonging to what could be described as the 'occidentalis' species-complex and a neotype for $K$. occidentalis is designated. Within this complex, two new species, $K$. kaata sp. nov., and $K$. shannonensis sp. nov. are described.
Aside from these new species designations, I have been unable to find reliable morphological characters to distinguish what I believe will ultimately prove to be a complex of species belonging to Kumbadjena gen. nov. This is typical for Australian Onychophora, particularly among populations that are geographically widespread. Morphological crypsis among populations occupying narrow distributional ranges is the norm, so the future discovery of new Kumbadjena gen. nov. species should not be surprising. However, until additional suites of characters are examined, such as allozymes, gene sequences, and/or karyology, it is not possible to determine the number of species present within this complex. Given the biological importance and significant conservation status of Onychophora, a detailed study based on additional characters should be a high priority for future research.

\section{Evolutionary relationships}

The results of a phylogenetic analysis undertaken by Reid (1996), which included 62 peripatopsids, showed Occiperipatoides occupying a basal position in the cladogram with respect to many of the remaining Australian peripatopsids (most of the latter formed part of a large, mostly unresolved clade). The Occiperipatoides clade was supported by six unambiguous apomorphies, only one of which was unique: the presence of crural glands extending the length of the body from anterior (the first pair of oncopods) to posterior. This result contrasts radically with that presented in Gleeson et al. (1998) 
of an analysis based on comparison of sequences from the mitochondrial cytochrome oxidase subunit I gene. In this analysis, Occiperipatoides (represented by $O$. gilesii from Jandakot $32^{\circ} 07^{\prime} \mathrm{S} ; 115^{\circ} 50^{\prime} \mathrm{E}$ ) occupies a more terminal position with respect to the other Australian taxa included in the study, though the resolution of the clade containing $O$. gilesii was poor. However, both analyses (Reid, 1996; Gleeson et al., 1998) show Euperipatoides Ruhberg, from eastern Australia, and Occiperipatoides to be sister taxa. There are some problems with both the morphological and molecular analyses of the peripatopsids that have been undertaken to date. Unfortunately it is still necessary to conclude that we know very little at present about the evolutionary relationships between the onychophorans from Western Australia and those from the rest of Australia and elsewhere.

\section{MATERIALS AND METHODS}

\section{Specimen collection and preservation}

This study is based on the examination of preserved specimens, most of which were hand collected from within and under decomposing logs and leaf litter. Specimens collected by the author were preserved, partially following the method of Reid (1996). Animals were anaesthetised by exposure to ethyl acetate vapour for $10 \mathrm{~min}$; dipped in $70 \%$ ethanol to render the cuticle less hydrophobic; fixed in $4 \%$ formalin for 2-3 days; then stored in $70 \%$ ethanol. Animals preserved in this way are distended, enabling characters to be examined more easily than is possible in contracted specimens. Formalin fixation allows internal structures (particularly the male reproductive tract) to be dissected and examined without tissue breakage.

\section{Tissue preparation for scanning electron microscopy}

Tissue dissected from fixed and preserved specimens was dehydrated in a graded ethanol series. Following three washes in $100 \%$ ethanol, tissue pieces were impregnated in hexamethyldisilazane (HMDS) by taking them though a graded ethanol/HMDS series to $100 \%$ HMDS, air dried and gold coated. Each step in the dehydration series lasted five minutes. Specimens were examined in a Philips 505 scanning electron microscope operated at $20.1 \mathrm{kv}$.

For males and females of all populations collected by the author, the following tissue samples were prepared for scanning electron microscopy (SEM) as above: dorsal integument; nephridiopores; crural papillae from oncopods 1, 3, 7 and 12; anterior accessory gland papillae and the area surrounding the posterior accessory gland foramen.

\section{Terminology}

Terminology for all characters follows Reid (1996). Head width is used as an indicator of size as this measure is less prone to variation due to the degree of distension of the body than are other size indicators such as total length. Except in the case of $K$. occidentalis, where measurements and counts are given, these refer only to type specimens. Measurement values are expressed as minimummean-maximum.

\section{Abbreviations}

EDI eye diameter index (eye diameter expressed as a proportion of head width)

HWE width of head measured dorsally between the midpoint of each eye

AM Australian Museum, Sydney, Australia

ANIC Australian National Insect Collection, Canberra, Australia

BMNH The Natural History Museum, London, United Kingdom

MNHN Muséum National d'Histoire Naturelle, Paris, France

QM Queensland Museum, Brisbane, Australia

WAM Western Australian Museum, Perth, Australia

$\mathrm{ZMH}$ Zoologisches Institut und Zoologisches Museum, Universität Hamburg, Hamburg, Germany

\section{Species boundaries}

In this study, species are defined on the basis of discrete morphological gaps that indicate the occurrence of species boundaries. The resulting inferences about species boundaries are working hypotheses, subject to further testing with genetic markers, behavioural observations, or additional morphological characters.

Not all morphological discontinuities, however, indicate species boundaries: they may be artifacts of insufficient sampling (many populations of Onychophora are indeed represented by only a few specimens) or reflect intraspecific polymorphism. Because of this, a conservative approach has been taken towards species determination. For the majority of populations of Kumbadjena gen. nov. observed variation may simply be the result of geographical variation. The nature of sampling over the range of the genus means that it is not possible to determine whether there is sympatry among phenotypes. If sympatry can be identified in future studies, populations can more confidently be assigned to distinct species. Careful genetic and ecological studies are needed to demonstrate whether the observed variation represents different species, intraspecific polymorphism, or an intermediate situation involving assortative mating and only partial reproductive isolation. Until these studies are undertaken, I prefer not to attempt to 
assign all Kumbadjena gen. nov. populations collected to date to one of the three species described below.

\section{SYSTEMATICS}

The Western Australian Onychophora could clearly be assigned to two genera on the basis of nine clear apomorphies distinguishing these taxa (Table 1). These two genera are described below as Occiperipatoides Ruhberg, and Kumbadjena gen. nov.

Within the Kumbadjena gen. nov. complex, the determination of species boundaries based only on morphological characters has proved problematic. Reid (1996) reported that populations representing this complex (formerly the $O$. 'occidentalis' complex) could be assigned to five putative species. However, the collection of more material has largely served to blur these boundaries rather that clarify them. Intra-population variation has swamped the supposed inter-species variation observed earlier. The main difficulty lies in the interpretation of colour patterns. While some patterns seem to be specific for particular populations, in all populations examined specimens were found that lacked any body pattern at all. Also, considerable variation can be found in colour patterns within a population, making diagnoses based on this trait difficult.

Some differences were found, however, in some populations in the structure of the crural papillae on the first pair of oncopods in males. Three variants of this structure were observed and as a result, three species within the complex can be recognised. As differences in this structure can only be seen in males using scanning electron microscopy, only those populations in which it was possible to study this trait in detail are recognised as belonging to one of the three species: $K$. occidentalis, K. kaata sp. nov. and $K$. shannonensis sp. nov. To assist with future studies, additional specimens belonging to this genus that cannot be reliably assigned to one of these three species are listed in the Appendix.

The type species of each genus is redescribed. Only those traits that differ from those described in the type species are included in new species descriptions.

\section{Kumbadjena gen. nov. Table 1}

Occiperipatoides Ruhberg, 1985 (in part): 123-124; table 1; Reid, 1996 (in part): 813-814, Figure 30.

\section{Type species}

Peripatus leuckarti var. occidentalis Fletcher, 1895.

\section{Diagnosis}

Dorsal primary papillar scales ribbed proximally and partially ribbed distally (microcristae fused at tips of scales) in both sexes. Fifteen oncopod pairs;

Table 1 Distinguishing features of Kumbadjena gen. nov. and Occiperipatoides Ruhberg.

\begin{tabular}{|c|c|}
\hline Kumbadjena gen. nov. & Occiperipatoides Ruhberg \\
\hline 15 oncopod pairs & 16 oncopod pairs \\
\hline $\begin{array}{l}\text { dorsal primary papillar scales ribbed proximally, } \\
\text { partially ribbed distally (microcristae fused at tips } \\
\text { of scales) in both sexes (Figures } 3 a, b ; 6 c, d ; 10 a, b ; 12 a, b \text { ) }\end{array}$ & $\begin{array}{l}\text { dorsal primary papillae with ribbed scales in both } \\
\text { sexes, microcristae not fused (Figure 14a) }\end{array}$ \\
\hline $\begin{array}{l}\text { first pair of oncopods greatly enlarged in males } \\
\text { (Figure 1); slightly enlarged in females }\end{array}$ & $\begin{array}{l}\text { first pair of oncopods not greatly enlarged, similar } \\
\text { in size to remaining oncopods }\end{array}$ \\
\hline $\begin{array}{l}\text { crural papillae oncopods } 1 \text { protrude between third } \\
\text { (proximal-most) spinous pad and adjacent plica }\end{array}$ & $\begin{array}{l}\text { crural papillae oncopods } 1 \text { protrude between } \\
\text { plicae } 2-3 \text { (counting from third spinous pad) }\end{array}$ \\
\hline $\begin{array}{l}\text { crural papillae oncopods } 2-14 \text { very broad basally, } \\
\text { conical distally, not elongate }\end{array}$ & $\begin{array}{l}\text { crural papillae oncopods } 1-15 \text { moderately broad } \\
\text { basally, cylindrical distally, elongate }\end{array}$ \\
\hline $\begin{array}{l}\text { crural papillar foramen oncopod } 1 \text { not obviously } \\
\text { demarcated (Figures } 3 c, 6 a, 10 c, 12 c, 13 \text { ) }\end{array}$ & $\begin{array}{l}\text { crural papillar foramen oncopod } 1 \text { demarcated } \\
\text { from rest of papilla by a smooth lip-shaped } \\
\text { margin (Figure } 14 \text { b). }\end{array}$ \\
\hline $\begin{array}{l}\text { anterior accessory glands long, extend anteriorly } \\
\text { approximately to oncopods } 11\end{array}$ & $\begin{array}{l}\text { anterior accessory glands moderate length, extend } \\
\text { anteriorly approximately to oncopods } 14 \text { or } 15\end{array}$ \\
\hline $\begin{array}{l}\text { posterior accessory gland foramen joined, } \\
\text { inverted Y-shaped (Figure } 3 \mathrm{~h} \text { ) }\end{array}$ & $\begin{array}{l}\text { posterior accessory gland foramen separate, not } \\
\text { joined, }>\text {-shaped }\end{array}$ \\
\hline $\begin{array}{l}\text { posterior accessory glands long and narrow, } \\
\text { uniform width (Figure } 4 \text { ) }\end{array}$ & $\begin{array}{l}\text { posterior accessory glands broad and saccate } \\
\text { (Figure 15) }\end{array}$ \\
\hline
\end{tabular}


first pair of oncopod feet enlarged in males, slightly enlarged in females. Crural papillae oncopods 1 protrude between third (proximal-most) spinous pad and adjacent plica; foramen not obviously demarcated from rest of papillae. Crural papillae oncopods 2-14 very broad basally, conical, not elongate distally; papillar scales and scale microcristae fused, or partially fused, smooth; foramen a transverse slit opening on inner side of smooth region. Posterior accessory gland foramen joined, inverted Y-shaped. Posterior accessory glands long and narrow, uniform width. Crural glands extending length of body from first pair of oncopods. Ovoviviparous, ova follicular.

\section{Remarks}

A new genus is proposed here for representatives of the O. 'occidentalis' species-complex because all of its members share a number unique characters that are not present in $O$. gilesii, the type species of the genus Occiperipatoides Ruhberg, 1985. The differences between these two genera are shown in Table 1 . In addition, $O$. gilesii from Mundaring $\left(31^{\circ} 51^{\prime} \mathrm{S} ; 116^{\circ} 10^{\prime} \mathrm{E}\right)$ and a representative of the $O$. 'occidentalis' species-complex from Ferguson R. $\left(33^{\circ} 23^{\prime} \mathrm{S} ; 115^{\circ} 45^{\circ} \mathrm{E}\right)$ were shown to differ at $81 \%$ of 21 allozyme loci by Briscoe and Tait (1995). This level of difference is similar to that observed between distinct onychophoran genera that were included in the same study.

The sister-group relationship between these two taxa was well supported in the phylogenetic analysis of Reid (1996), and given the distributions

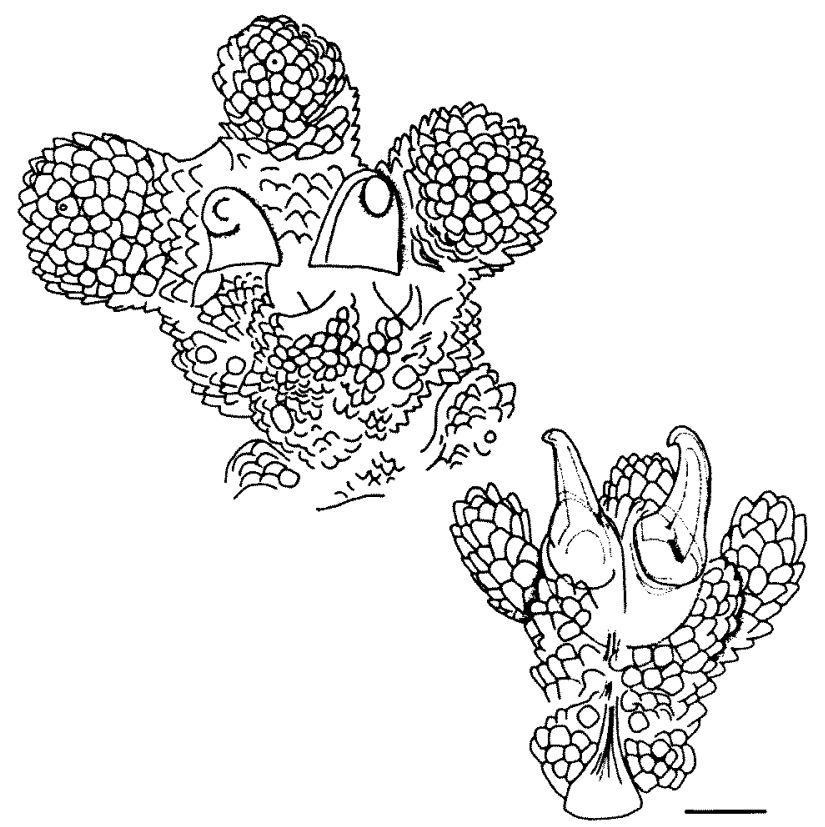

Figure 1 Kumbadjena shannonensis sp. nov: $a$, ventral foot oncopod $1 ; b$, ventral foot oncopod 2 , drawn to the same scale, male $0.99 \mathrm{~mm}$ HWE (WAM 91/1132). Scale bar $0.05 \mathrm{~mm}$. (Figure reproduced from Reid, 1996: 821.) of these two species, both occurring in the southwestern corner of Western Australia, is not surprising.

The enlarged feet on the first pair of oncopods of males of this genus (Figure 1) can be seen in males of all sizes examined, including juveniles and unborn specimens (presumably males but not possible to sex by other means) present in the uteri.

\section{Etymology}

The generic name is composed of words borrowed from the Nyungar dialect, a language spoken by the Aboriginal inhabitants of southwestern Western Australia (Dench, 1999). Kumba, means 'big', and djena, 'foot'. The name refers to the enlarged first oncopod feet in members of this genus. Gender feminine.

\section{Kumbadjena occidentalis (Fletcher), comb. nov.} Figures 2-4, 8

Peripatus leuckarti var. occidentalis Fletcher, 1895: 185-186.

Peripatoides occidentalis. - Dakin, 1914a: 289-292, text figure 1; Dakin, 1914b: 3-5; Dakin, 1920: 367389, plates $I-V$, figures $1-25$ (in part).

Occiperipatoides occidentalis. - Ruhberg, 1985: 126; Tait et al., 1990: 1253-171, table 1; Briscoe and Tait, 1995: 91-102, tables 1 and 3; Reid, 1996: 817-819, figures $97-98$.

\section{Material examined}

\section{Neotype}

o Western Australia, Bridgetown Jarrah Park, $20.3 \mathrm{~km}$ west of intersection of South Western Hwy and Brockman Hwy, 34 $01^{\circ} \mathrm{S} ; 116^{\circ} 00^{\prime} \mathrm{E}, 250 \mathrm{~m}, 3 \mathrm{Apr}$ 2000, coll. A. Reid and R. Roberts (WAM T42554).

\section{Other material examined}

Western Australia: 13 $\delta^{\star}, 13 q, 1$ juv., data as for neotype (WAM T42555); $1 \delta$, 2 \% , 1 juv., Karri Gully, $25.4 \mathrm{~km}$ west of intersection of South Western Hwy and Brockman Hwy, 34.01'S; $115^{\circ} 58^{\prime} \mathrm{E}, 300 \mathrm{~m}, 2 \mathrm{Apr}$ 2000, coll. A. Reid and R. Roberts (WAM T42556).

\section{Diagnosis}

Dorsomedially body indistinctly patterned, or not patterned. Crural papillae on oncopod 1 broad basally, abruptly tapered, cylindrical distally; crural papillae on oncopods 2-14 broad basally, abruptly tapered, conical, blunt distally. Crural papillae on oncopod 1 with finely ribbed scales basally, distally scales with distinct ribs; oncopods 2-14 crural papillae with finely ribbed scales basally, smooth distally (only very slightly crenulated), papillar scales and microcristae fused. 


\section{Description}

\section{Measurements}

HWE males 0.90-1.02-1.07 mm ( $\mathrm{n}=15$, neotype $1.07 \mathrm{~mm}$ HWE); females 1.05-1.16-1.25 mm ( $\mathrm{n}=14)$.

\section{Colour pattern}

Body pigmented. Pigment not soluble in alcohol. Dorsomedially body indistinctly patterned, or not patterned; ground-colour tan, orange, or greyish-blue; primary papillae lightcoloured basally, dark tipped. Mid-dorsal dark stripe absent; every fourth plica with 1-2 darkcoloured papillae on each side of mid-dorsal line (Figure 2a) (not clearly visible in dark ground colour specimens (Figure 2b)); rest of dorsal integument with regular mottling, scattered lightbased papillae (Figure $2 \mathrm{~b}$ ), or, tan and orange specimens with dark longitudinal bands dorsolaterally (Figure 2a). Few specimens with indistinct regular pattern of series of dark crosses (arms of crosses extend toward oncopods) over indistinct lighter-coloured diamonds (Figure 2c).
Laterally with longitudinal light-coloured band dorsal to oncopods, or with light-coloured patches between oncopods. Some specimens with dark longitudinal bands immediately above and between oncopods. Oncopods colour similar to, or slightly paler than body; with light-coloured patches at junction with feet. Papillae around anal opening pigmented as for rest of body. Ventral pigment very pale; dark patches between ventral organs and base of oncopods. Spinous pads pale yellow or greyish-blue. Integument between genital and anal openings pigmented as for rest of ventrum, or darker than rest of ventrum.

Antennal rings banded: $\tan$ or with tan mottle dorsally and ventrally, or not banded, groundcolour; when present, dorsal banding on every fourth ring distal to and including ring five, or in tan and brown specimens, proximal half to twothirds of antennae tan, sometimes with some greyish-blue pigment on each antennal ring; distal half to two-thirds of antennae greyish-blue.

Newborn animals and posterior-most embryos in uteri pigmented.
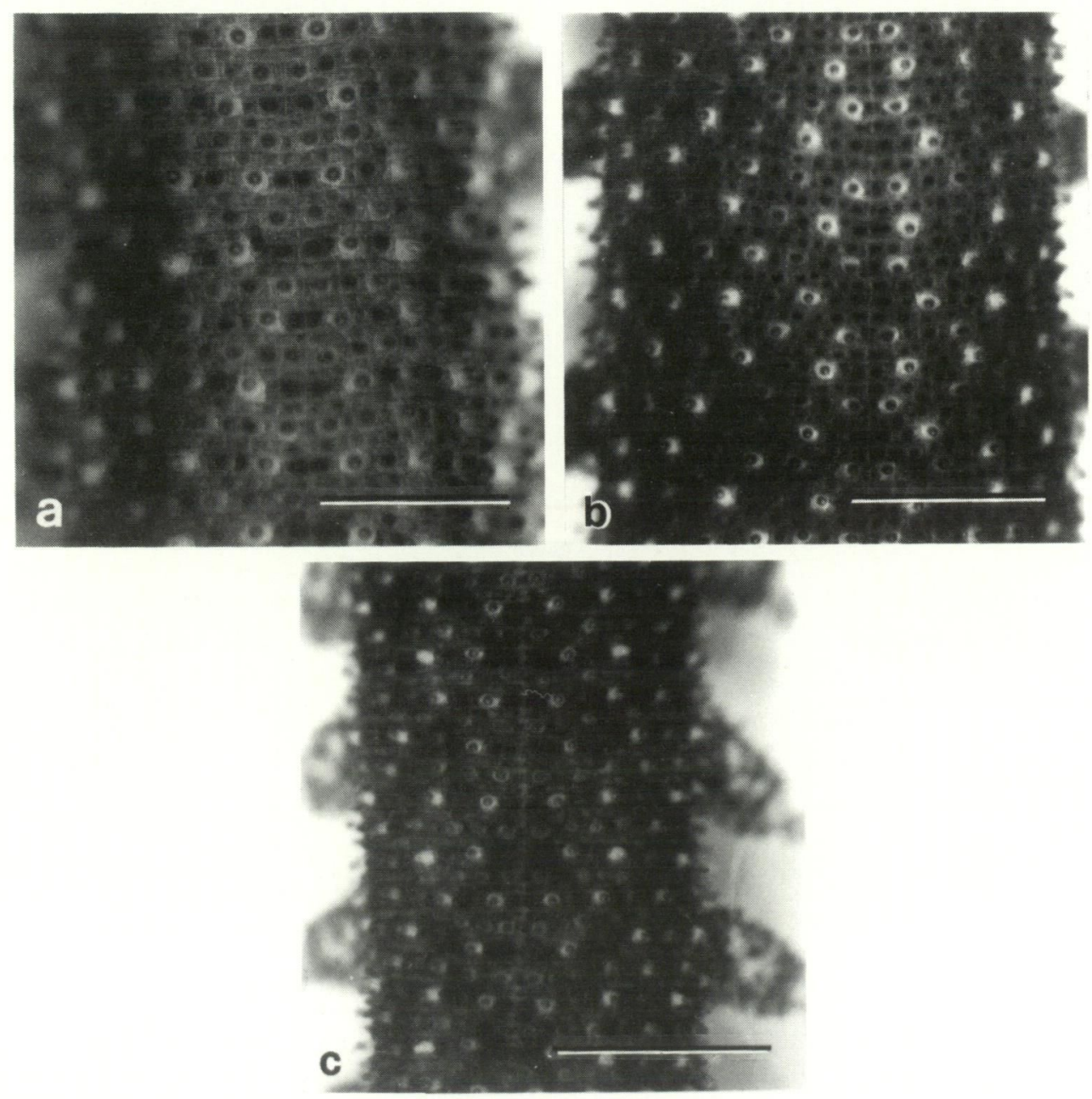

Figure 2 Kumbadjena occidentalis (Fletcher), dorsal integument: $a$, male $1.00 \mathrm{~mm}$ HWE (WAM T42555); $b$, female 1.20 mm HWE (WAM T42555); c, male $1.0 \mathrm{~mm}$ HWE (WAM T42555). Scale bars $1.0 \mathrm{~mm}$. 

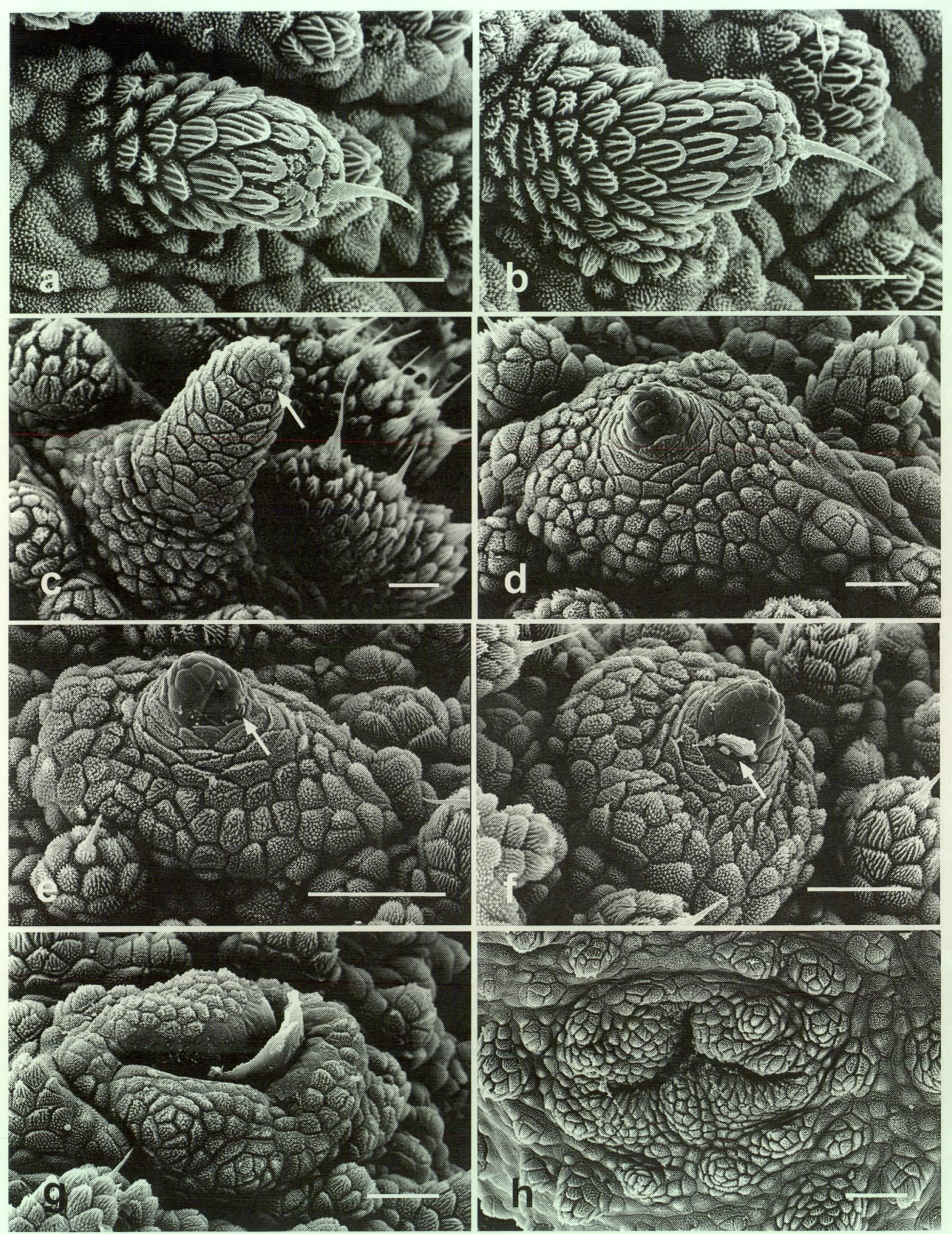

Figure 3 Kumbadjena occidentalis (Fletcher) (SEM's): $a$, primary papilla, male 1.05 mm HWE (WAM T42555); $b$, primary papilla, female $1.25 \mathrm{~mm}$ HWE (WAM T42555); $c$, crural papilla oncopod 1, male, $1.00 \mathrm{~mm}$ HWE (WAM T42555), arrow indicates foramen; $d$, crural papilla oncopod 3, male, $1.00 \mathrm{~mm}$ HWE (WAM T42555); $e$, crural papilla oncopod 7, male $1.0 \mathrm{~mm}$ HWE (WAM T42555), arrow indicates foramen; $f$, crural papilla oncopod 12, male $1.00 \mathrm{~mm}$ HWE (WAM T42555), arrow indicates foramen (partly obscured by crural gland exudate); $g$, anterior accessory gland papilla, male $0.90 \mathrm{~mm}$ HWE (WAM T42555); $h$, posterior accessory gland foramen, male $1.07 \mathrm{~mm}$ HWE (WAM T42555). Scale bars $a-g, 100 \mu \mathrm{m}, h, 200 \mu \mathrm{m}$. 
Antennae

Approximately 30 antennal rings in adults and juveniles; wide and narrower antennal rings alternate; two rows of bristles on rings (counting from distal to proximal) $3,4,6,8,12$, or $3,6,9$. Distal $7-10$ antennal rings with sensory bulbs. Proximal antennal rings expanded ventrally to form sensory pads; sensory pads with up to $2-3$ rows of sensilla.

Eyes

EDI males 0.05-0.10-0.12; females $0.10-0.11-0.12$.

\section{Head (males)}

Males with no modification of head papillae (i.e. papillae on head do not differ from remaining dorsal papillae). Eversible head structure absent.

\section{Head (females)}

Females with no modification of head papillae.

Jaws

Inner jaw with 5-6 denticles; diastema absent; outer jaw without accessory tooth. Tongue with longitudinal row of 5-6 teeth. Buccal folds in single unbroken row.

\section{Integument}

Dorsum with 12 complete plicae between oncopods; wide and narrower plical folds alternate. Males with 11-13-15, females with 13-15-18 papillae counted from mid-dorsal line to junction of oncopod 10. Dorsal body papillae approximately uniform size; alternate plicae with slightly larger primary papillae; primary papilla with short, narrow bristle between pair of larger primary papillae with longer, more robust bristles and smaller secondary papillae between primary papillae; dorsal primary papillae cylindrical; conical apical piece absent; papillar scales ribbed proximally (microcristae well defined), partially ribbed distally (microcristae fused at tips of scales) in both sexes (Figure 3a,b); lateral primary papillae slightly enlarged or elongate, with more prominent pair between oncopods in line with junction of oncopods and body; papillae around anal opening slightly larger than those on rest of body; remaining integument with small scales.

\section{Oncopods}

Fifteen pairs in both sexes. First pair of oncopod feet enlarged in males, slightly enlarged in females. Last pair of oncopods well developed in both sexes, orientation as for remaining oncopods. Basal foot papillae absent. Distal foot papillae one anterior, one median, one posterior; both sexes with 1-2 bristles on anterior distal foot papillae oncopod one, $1-2$ bristles on posterior distal foot papillae and one bristle on median foot papillae. Distal foot papillae on remaining feet each with single sensory bristle. With three complete spinous pads; fourth broken spinous pad present. Spinous pads well-developed on all oncopods. Nephridiopores at centre of third spinous pad on fourth and fifth oncopod pairs; nephridiopore foramen U-shaped.

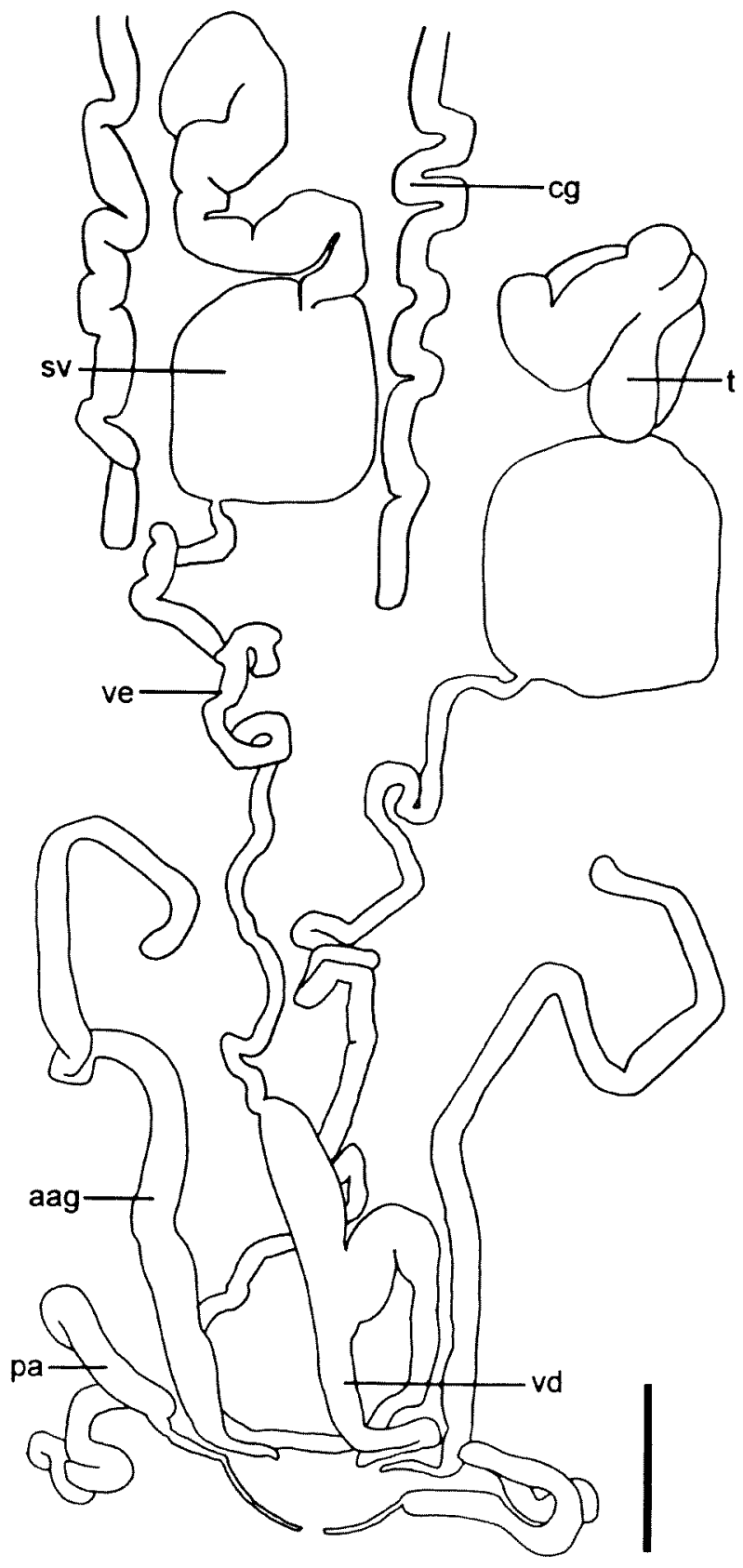

Figure 4 Kumbadjena occidentalis (Fletcher). Male reproductive tract and associated glands: male $1.05 \mathrm{~mm}$ HWE (WAM T42555); aag, anterior accessory gland; $\mathrm{cg}$, crural gland; $\mathrm{pa}$, posterior accessory gland; sv, seminal vesicle; $t$, testis; vd, vas deferens; ve, vas efferens. (Only the posterior parts of the crural glands are shown. They extend anteriorly to oncopod 1.) Scale bar $2 \mathrm{~mm}$. 


\section{Male reproductive tract}

Male genital pad low, semicircular; gonopore cruciform (with arms equidistant), arms extending close to rim of genital pad. Vasa efferentia with thin, flexible walls; proximal vasa efferentia separate, do not lie parallel, or lie parallel for part of their length before fusing to form vas deferens; broad; vas deferens continues directly (without looping posteriorly) from paired vasa efferentia to gonopore (Figure 4), not thick walled, opaque, not shiny. Spermatophore pouch present.

\section{Male glands and gland papillae}

Crural papillae, one per oncopod, present on ventral side of oncopods 1-14; protrude between third (proximal-most) spinous pad and adjacent plica (oncopod 1), or between plicae 4-5 (counting from third spinous pad) on oncopods 2-14. Papillae shape differs among oncopods: papillae broad, semicircular proximally, cylindrical distally, divided into distinct basal and distal regions (oncopod 1), or broad based, semicircular proximally, abruptly tapered, conical, blunt distally (oncopods 2-14); with finely ribbed scales basally, distally scales with distinct ribs (oncopod 1) (Figure $3 c$ ), or with finely ribbed scales basally, smooth distally (very slightly crenulated), papillar scales and microcristae fused oncopods 2-14 (Figure 3df); crural papillae oncopods 1 open close to, but slightly proximal to distal tip of papilla via a short slit (Figure 3c); crural papillae oncopods 2-14 open via a long transverse slit on inner side of papilla at base of smooth region (Figure $3 \mathrm{e}, \mathrm{f}$ ). Crural glands extend into lateral haemocoel from oncopod 1, or do not extend into lateral haemocoel, confined to oncopods (oncopods 2-14); glands extending from oncopods 1 straight, extend length of body posteriorly to oncopod 11 (Figure 4). Coxal organs absent. Anterior accessory gland papillae on genital segment at base of last pair of oncopods; do not protrude significantly, with ill-defined margins; without smooth distal region; foramen a longitudinal slit (Figure $3 \mathrm{~g}$ ). Anterior accessory glands present; long; lying freely within perivisceral haemocoel; extending anteriorly approximately to oncopods 11 (Figure 4). Posterior accessory glands present; foramen approximately midway between genital and anal openings; gland foramen joined, forming inverted $Y$ shape (Figure $3 \mathrm{~h}$ ); glands long narrow, approximately uniform width (taper slightly distally), folded (Figure 4).

\section{Female reproductive tract}

Females without ovipositor; ovoviviparous; gonopore not borne on raised pad; foramen shape cruciform, (with arms equidistant). Ovarian tubes separate, suspended along entire length to pericardial floor; with thin walls; oviducts unite close to ovary; ova follicular. Spermathecae present; open into oviducts via single duct. Additional pouches present. Embryos in individual uteri at successive stages of development along length of uteri.

\section{Female glands and gland papillae}

Crural papillae absent (see Remarks). Uterine glands absent.

\section{Remarks}

Fletcher's (1895) description of $P$. occidentalis was based on some specimens that were sent to him in Sydney by A. M. Lea. Lea was the Government Entomologist of Western Australia from 1895-1898, and was later based at the South Australian Museum. The locality name in the description was given only as 'Bridgetown', no type specimens were designated, and the depository for the specimens was not indicated. Despite considerable searching and correspondence to a number of institutions (including the South Australian Museum), the types have not been traced. For this reason, a neotype is designated here to define the nominal taxon. Because the original description is not very detailed and there are no illustrations, the designation of a neotype is necessary to enable comparisons to be made between $K$. occidentalis and other taxa.

According to the International Code of Zoological Nomenclature (1999) a neotype must come from, 'as nearly as practicable from the original type locality' (Article 75.3.6: 85). Despite extensive searching over a number of days on two fieldtrips (one in May 1995, and the other in April 2000), no onychophorans were found in the immediate vicinity of Bridgetown.

A number of possibilities could explain why we were unable to find specimens in Bridgetown:

1. The area surrounding Bridgetown itself was very dry and largely cleared, in marked contrast to the forest in the Bridgetown Jarrah Park from which specimens were easily found. It is possible that Bridgetown may have experienced a higher rainfall (and therefore more suitable onychophoran habitat) over a century ago when the specimens were collected. This possibility is likely as it is well known that extensive land clearing, as has occurred in the vicinity of Bridgetown over the last hundred years, can radically alter localised rainfall patterns. Indeed, it appears that there has been a significant decrease in annual precipitation at Bridgetown over the period for which records are available (1888-1999) (Figure 5). Whether this has any bearing on onychophoran distribution, or if other correlates have greater significance, is unknown.

2. The collector may have used the locality name 'Bridgetown' for the specimens he collected because it was the nearest named place to 


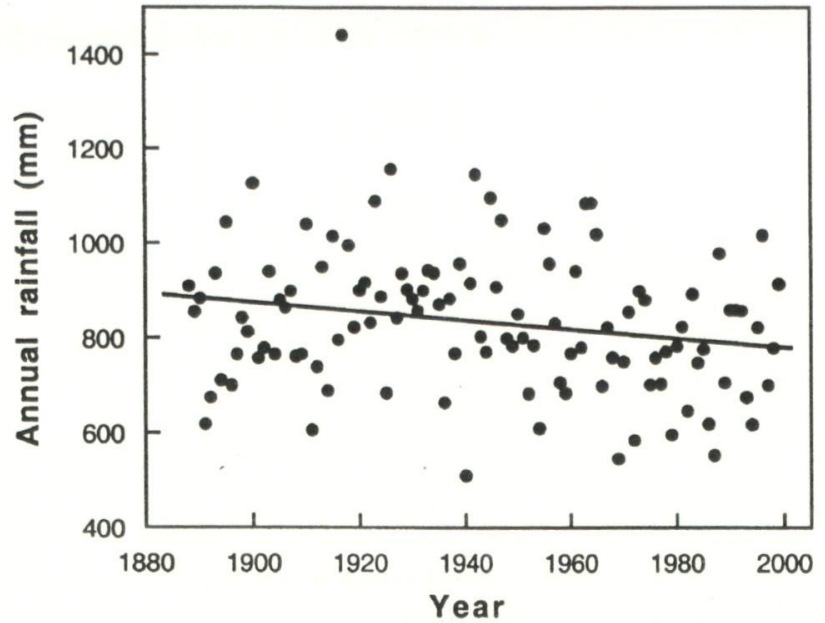

Figure 5 Annual rainfall measured at Bridgetown, WA, $33^{\circ} 57^{\prime} 28^{\prime \prime} \mathrm{S} ; 116^{\circ} 08^{\prime} 12^{\prime \prime} \mathrm{E}$ for the period 1888-1999. Regression of annual rainfall against time (plotted as yearly averages). Regression equation $Y=-0.937 \mathrm{X}+2656.1 ; P$ $=0.0105(P<0.05), r^{2}=0.017 \cdot r^{2}=$ proportion of total variation accounted for by regression. Data obtained from the Severe Weather Section Regional Office of the Bureau of Meteorology, Perth.

where the specimens were found, rather than the exact locality. If this is the case, the type specimens may not have been found in the immediate vicinity of the town.

3. Onychophorans do occur at Bridgetown but they have not yet been found.

Despite this latter possibility I have decided, in order to stabilise the taxonomy and nomenclature pertaining to this species, to designate a neotype from our available material. The neotype was selected from the nearest possible place to Bridgetown: the Bridgetown Jarrah Park, approximately 12.5 kilometres west of the town (20.3 kilometres by road).

The $K$. occidentalis specimens from Bridgetown Jarrah Park described above agree with the original description in all but one of the few characters that were used to diagnose the species. Fletcher (1895: $185)$ notes, 'the males have white papillae on most of the legs, but not on those of the first pair'. If he is referring to the crural papillae in this statement (which seems likely, as they are most obviously white on each oncopod), the specimens described here differ in having crural papillae on the first pair of oncopods. All the male Western Australian Onychophora I have examined to date have crural papillae on the first pair of oncopods. It may be that Fletcher overlooked these papillae because their position on the first pair of oncopods differs from
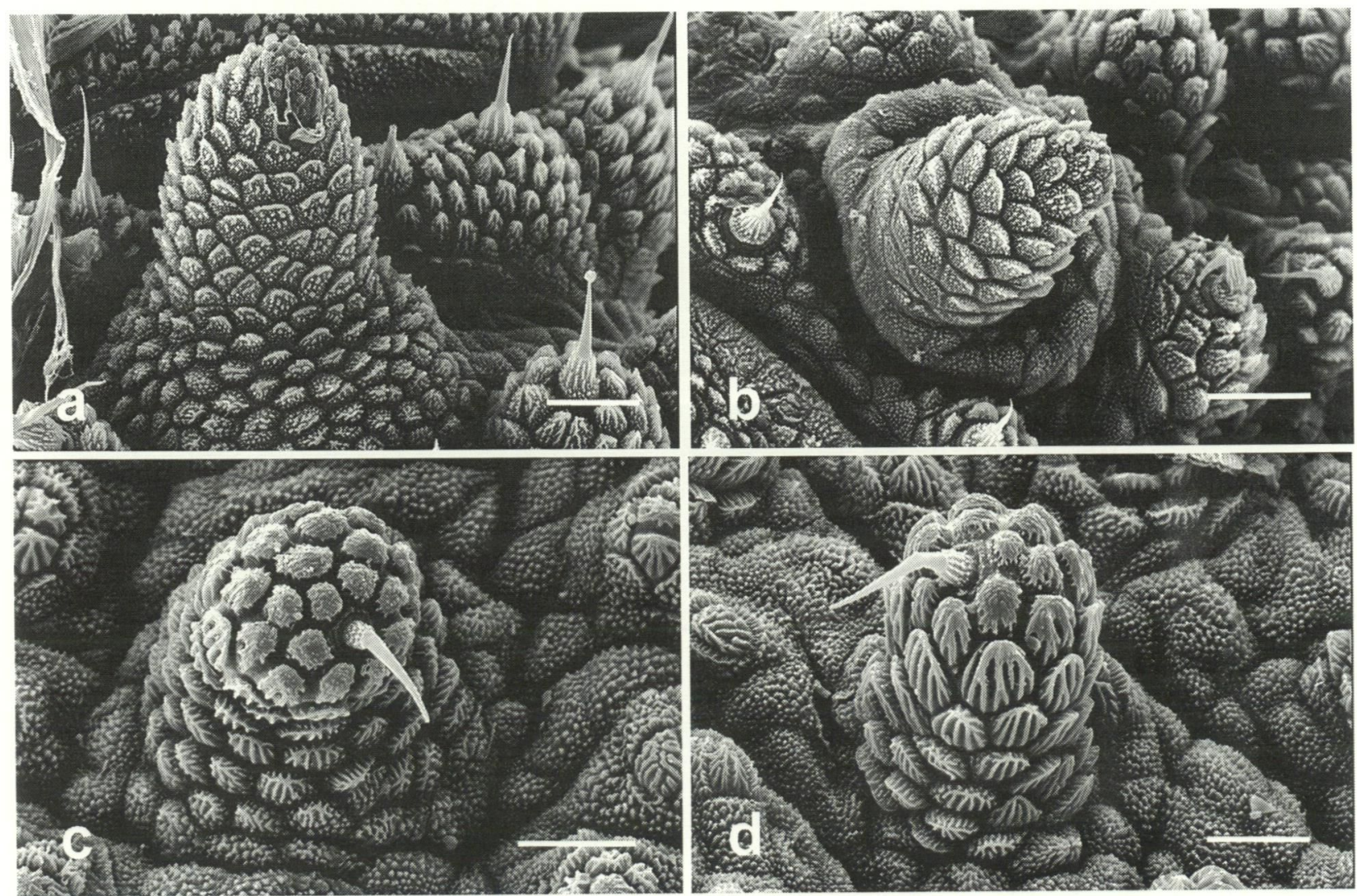

Figure 6 SEM's: $a$, crural papilla oncopod 1, male 1.20 mm HWE, Big Brooke SF (WAM T42566); $b$, crural papilla oncopod 1, male $0.98 \mathrm{~mm}$ HWE, Leeuwin Naturaliste NP (WAM T42561); c, primary papilla, male $0.98 \mathrm{~mm}$ HWE, Leeuwin Naturaliste NP (WAM T42561); d, primary papilla, female $1.05 \mathrm{~mm}$ HWE, Leeuwin Naturaliste NP (WAM T42561). Scale bars $a, b, 100 \mu \mathrm{m} ; c, d, 50 \mu \mathrm{m}$. 
those on the remaining oncopods. Because the crural papillae on the first oncopod pair are positioned distally and abut the third spinous pad, they are not as obvious as those on the other oncopods, particularly if they are retracted.

Dakin (1920) noted the presence of crural glands in female Occiperipatoides. He stated that they occur only occasionally and, 'when found there is no regularity as to the legs containing them' (Dakin, 1920: 379). In his paper, Dakin referred to a single species, Peripatoides occidentalis, and calls the northern form (here referred to as Occiperipatoides gilesii) Peripatoides occidentalis var. gilesii. For this reason it is difficult to determine from his detailed anatomical study to which species he refers in describing the presence of crural glands in females. No attempt was made in this study to section the oncopods of females to look for crural papillae, and no crural glands were observed in any of the specimens examined. However, because of Dakin's (1920) remarks, the possibility that crural glands do occur in females of either Western Australian genus cannot be excluded.
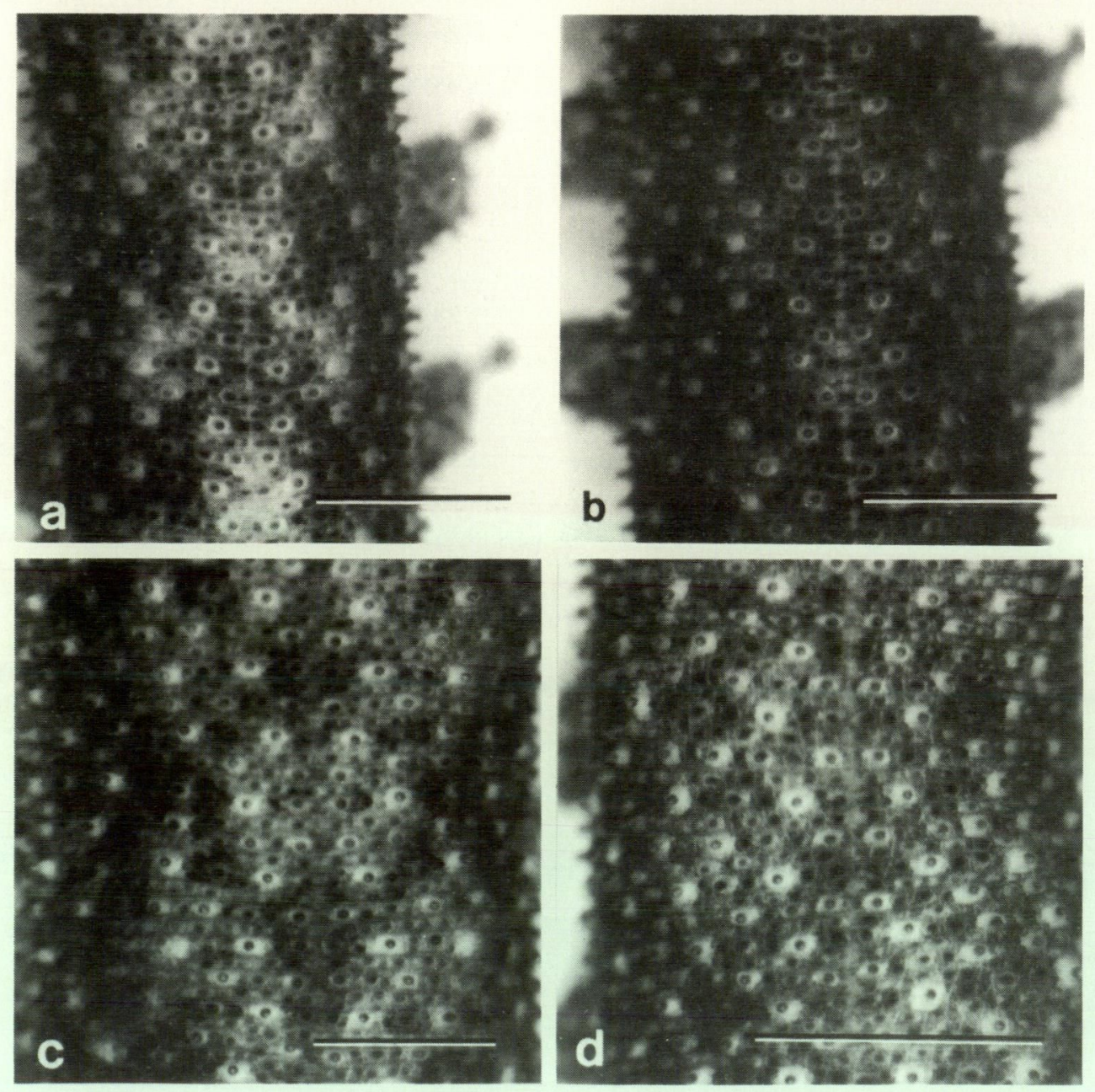

Figure 7 Dorsal integument: $a$, female $1.17 \mathrm{~mm}$ HWE, Big Brooke SF (WAM T42566); $b$, male $1.20 \mathrm{~mm}$ HWE, Big Brooke SF (WAM T42566); $c$, female 1.12 mm HWE, Leeuwin Naturaliste NP (WAM T42562); $d$, male 1.00 mm HWE, Leeuwin Naturaliste NP (WAM T42562). Scale bars $1.0 \mathrm{~mm}$.
The description of this species given in Reid (1996) was based on the only specimens available to the author at that time from as close as possible to the type locality, but some distance away (the Shannon River area, approximately $34^{\circ} 46^{\prime}$ 'S $\left.116^{\circ} 22^{\prime} \mathrm{E}\right)$. Examination of more material in the present study, and more importantly, specimens from close to the type locality has shown that the Shannon River specimens belong to a new species described here as $K$. shannonensis sp. nov.

Specimens from the Leeuwin Naturaliste National Park and Big Brooke State Forest (see Appendix) are very similar to $K$. occidentalis, particularly in the lack of fusion of the distal scale microcristae on the crural papillae of oncopods 1 (Figure $6 a, b$ ), which is diagnostic for $K$. occidentalis. They differ from $K$. occidentalis in that some (but not all) specimens are distinctively patterned (Figure $7 \mathrm{a}-\mathrm{d}$ ). In addition, the general body papillar scale microcristae show a greater degree of fusion on the distal papillar scales in specimens from the Leeuwin Naturaliste NP than those of $K$. occidentalis (Figure $6 \mathrm{c}, \mathrm{d}$, compare with Figure $3 a, b)$. For these reasons the specimens from 


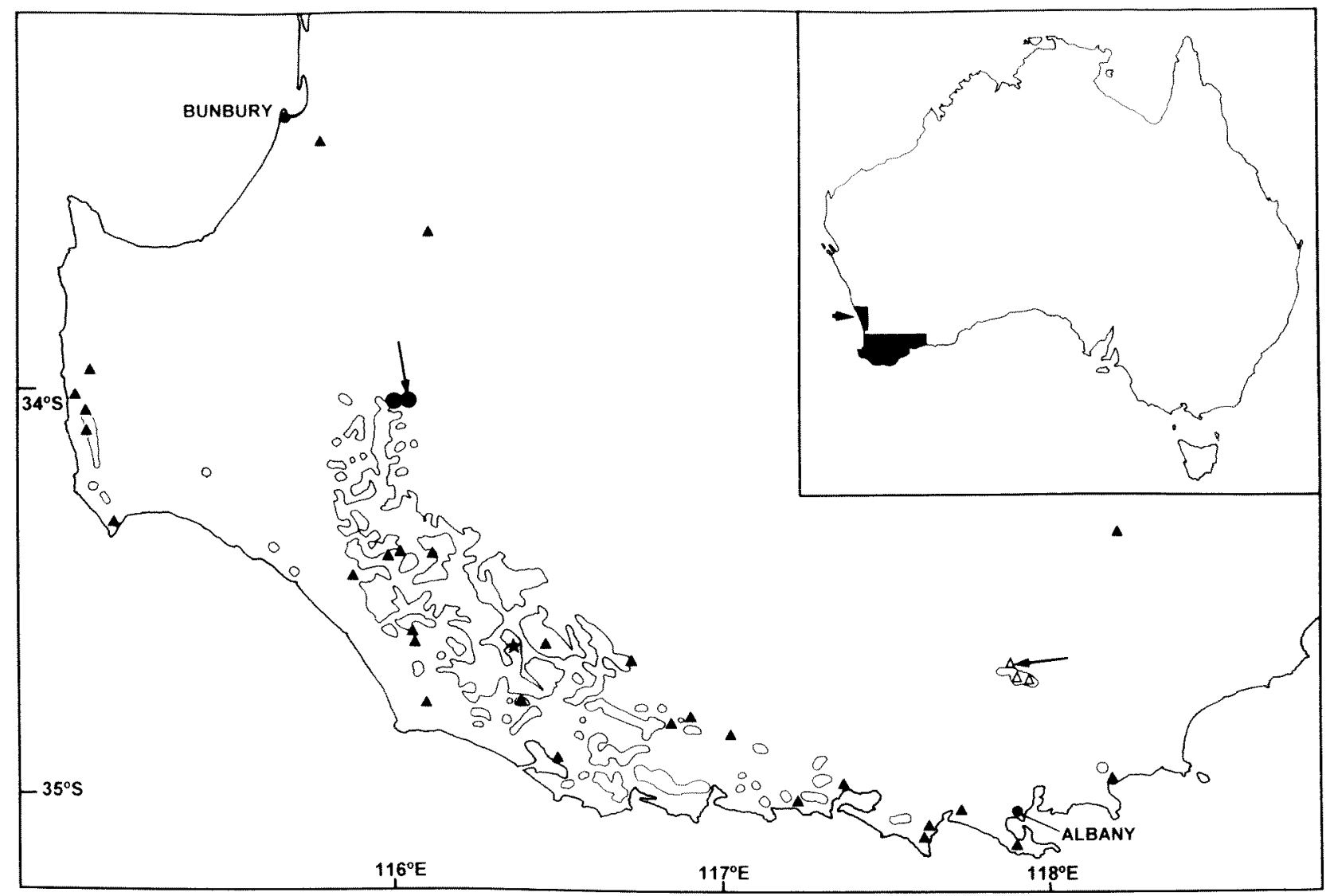

Figure 8 Distribution of Kumbadjena gen. nov. in south-western Western Australia. Area corresponds to lower shaded block in inset map of Australia. Large solid circles, $K$. occidentalis (Fletcher), arrow indicates type locality; open triangles, $K$. kaata sp. nov., arrow indicates type locality; star, $K$. shannonensis sp. nov.; solid triangles, $K$. spp. (species not determined). The occurrence of karri, E. diversicolor is indicated by 'islands' marked within the map (data obtained from Christensen, 1992: 6, figure 1). The arrow on the inset map indicates the geographical position of the enlargement shown in Figure 16 (O. gilesii distribution).

these two localities are not assigned to $K$. occidentalis.

\section{Habitat}

In and under rotting logs. Hand collected specimens were usually lying flat and straight when first exposed.

\section{Distribution}

Western Australia: Bridgetown Jarrah Park, $34^{\circ} 00^{\prime} \mathrm{S} ; 116^{\circ} 00^{\prime} \mathrm{E}$ to Karri Gully $34^{\circ} 01^{\prime} \mathrm{S} ; 115^{\circ} 58^{\prime} \mathrm{E}$ (Figure 8).

\section{Kumbadjena kaata sp. nov.}

Figures 8-10

\section{Material examined}

\section{Holotype}

t Western Australia, Porongurup NP, Scenic Drive, $3.1 \mathrm{~km} \mathrm{~W}$ of intersection of Scenic Drive and Bolganup Rd., 34 $39^{\circ} \mathrm{S}$; $117^{\circ} 51^{\prime} \mathrm{E}, 320 \mathrm{~m}, 11$ Apr 2000, coll. A. Reid and R. Roberts (WAM T42557).

\section{Paratypes}

$18 \delta^{\circ}, 4 \uparrow, 4$ juv., data as for holotype (WAM $\mathrm{T} 42558)$.

\section{Other material examined}

Western Australia: $6 \delta^{*}, 5 \%$, Porongurups Ra., 4 Mar 1994, coll. Monteith and Janetzki (QM S29906); 18, Porongurup NP, 6 Mar 1979 (AM KS14993); $1 \delta$, Porongurup NP, (AM KS14528); $1 \delta$, 19, 1 juv., Porongurup NP, $34^{\circ} 41^{\prime}$ '; $117^{\circ} 52^{\prime} \mathrm{E}, 7$ Oct 1981, coll. I. D. Naumann and J. C. Cardale (ANIC); $1 \%$, Porongurup NP, S. end of Millinup Pass, $34^{\circ} 42^{\prime} \mathrm{S}$; $117^{\circ} 54^{\prime} \mathrm{E}, 30 \mathrm{Mar} 1993$, coll. M. S. Harvey and J. M. Waldock (WAM 95/499); 29 , data as for previous (WAM 95/491-3); 10, 39, 31 Mar 1993, coll. M. S. Harvey and J. M. Waldock (WAM 95/ 494-7); $1 \delta$, Porongurups Ra., 1.85 miles $(3 \mathrm{~km})$ along scenic drive to Woodlands Rd from Bolganup Dam, 15 Feb 1974, A. Solem (FMNH).

\section{Diagnosis}

One to three rows of 1-3 dark papillae on each side of dorsal midline, remaining dorsal integument with regular mottling. Crural papillae oncopods 2- 
14 abruptly tapered, broad basally, conical distally. Crural papillae with finely ribbed scales basally, smooth distally; papillar scales and microcristae fused completely at base of smooth region, only partially fused at distal tips giving knobbly appearance (most obvious on crural papilla on oncopod 1).

\section{Description}

\section{Measurements}

HWE males 1.00-1.09-1.20 mm ( $\mathrm{n}=14$, holotype $0.12 \mathrm{~mm}$ HWE); females 1.00-1.13-1.25 mm ( $\mathrm{n}=11)$.

\section{Colour pattern}

Ground colour tan, grey, buff brown, or greyishblue; primary papillae unicolorous, or lightcoloured basally, dark tipped. Most specimens with 1-3 rows of 1-3 dark brown or black papillae (median pair darkest) on each side of dorsal midline forming distinct patches dorsal to and between each oncopod pair (those between each oncopod pair most pronounced) (Figure 9a), sometimes forming dark median stripe (Figure 9b); rest of dorsum with regular mottling (Figure 9c) (particularly in tan specimens), light-coloured median band bordered by darker pigment (Figure 9a), or not patterned (usually dark specimens) (Figure 9d). Some specimens with longitudinal light-coloured band laterally, dorsal to oncopods (one male with prominent broad tan band), or some specimens with light-coloured patches dorsal to oncopods. Papillae around anal opening pigmented as for rest of body. Tan specimens with dark grey patches beside ventral organs. Spinous pads tan or grey.

Antennal rings not banded, ground-colour (greyish blue specimens), or banded, tan or with tan mottle dorsally for half antennal length (tan and brown specimens); dorsal banding on alternate rings distal to, and including ring five, or (in tan and brown specimens), proximal half to two-thirds of antennae tan, sometimes with greyish-blue pigment on each antennal ring, distal half to twothirds of antennae greyish-blue (ventral banding present only in tan specimens, usually concentrated on basal antennal rings).
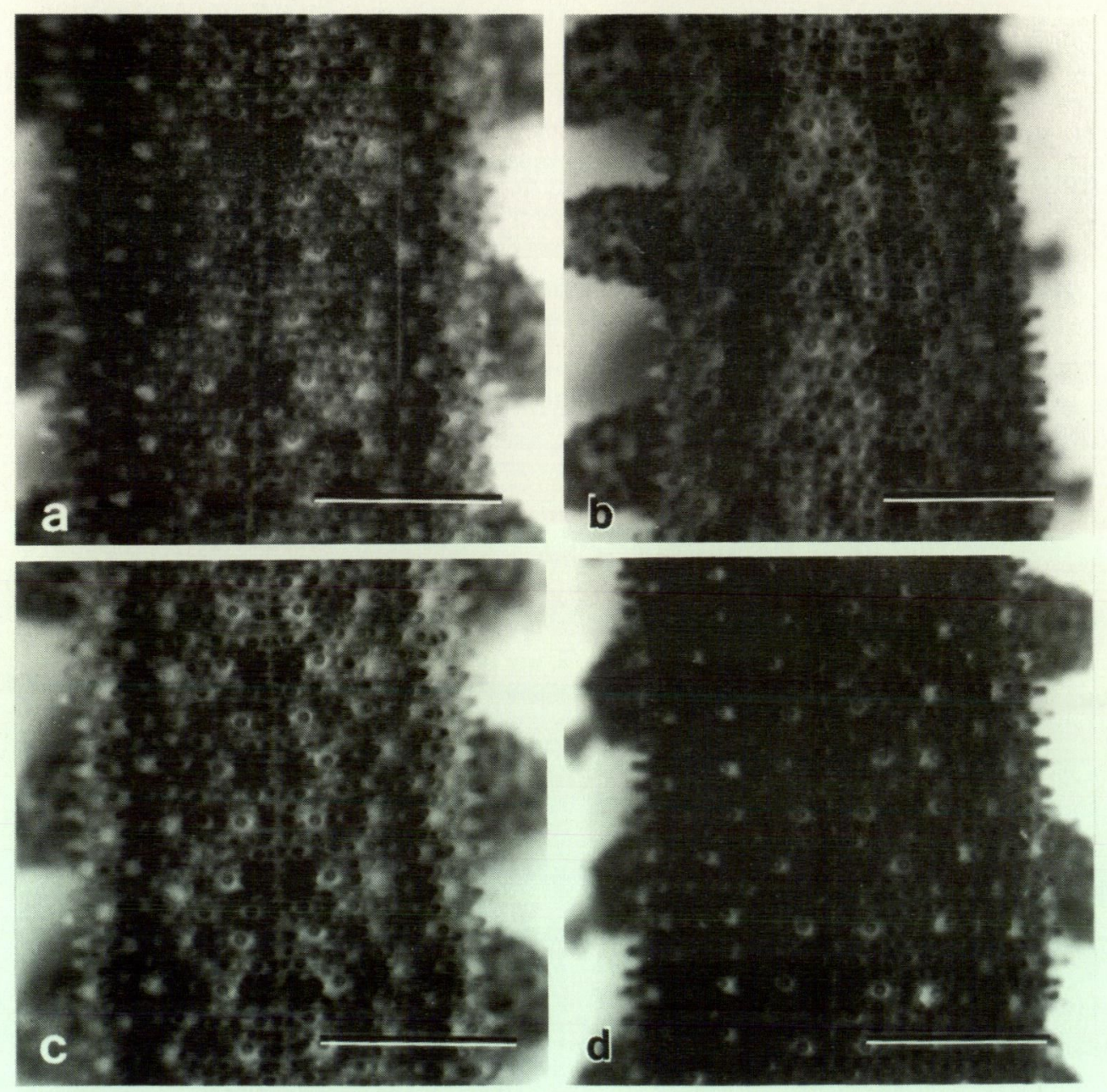

Figure 9 Kumbadjena kaata sp. nov., dorsal integument: $a$, male paratype $1.10 \mathrm{~mm}$ HWE (WAM T42558); $b$, male paratype $1.20 \mathrm{~mm}$ HWE (WAM T42558); $c$, female paratype $1.05 \mathrm{~mm}$ HWE (WAM T42558); $d$, male paratype $1.10 \mathrm{~mm}$ HWE (WAM T42558). Scale bars $1.0 \mathrm{~mm}$. 
Newborn animals pigmented.

\section{Antennae}

Two rows of bristles on rings (counting from distal to proximal) 3, 4, 6, 8. Distal 8-9 antennal rings with sensory bulbs. Sensory pads with up to three rows of sensilla.

Eyes

EDI males 0.10-0.11-0.12; females 0.09-0.11-0.12.

\section{Integument}

Males with 10-13-16, females with 12-14-20 papillae counted from mid-dorsal line to junction of oncopod 10. Papillar scales ribbed proximally, partially ribbed distally (microcristae fused at tips of scales) in both sexes (Figure 10a,b).

\section{Oncopods}

Males with 1-3 bristles on anterior distal foot papillae oncopod one; $1-2$ bristles on posterior
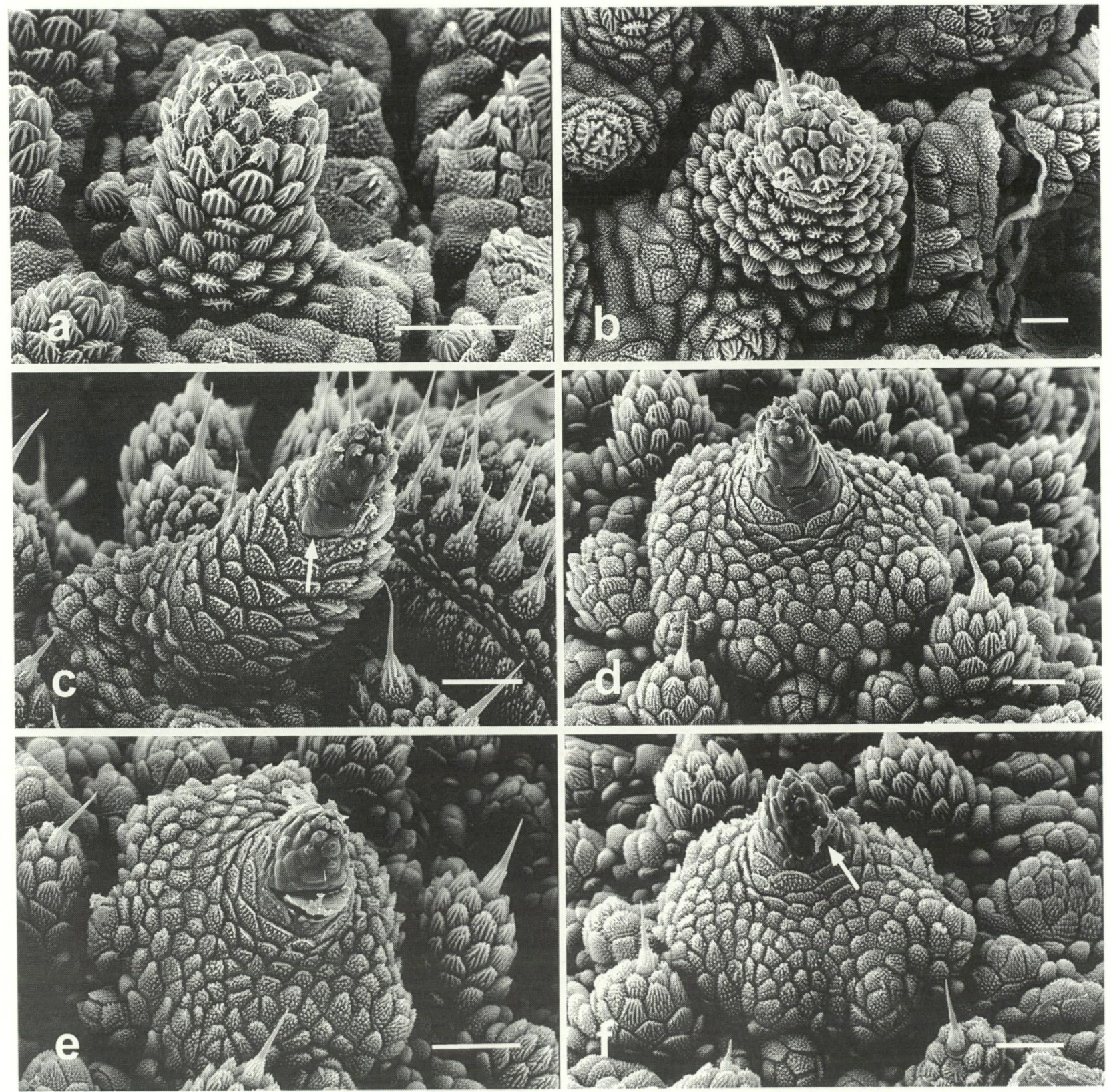

Figure 10 Kumbadjena kaata sp. nov. (SEM's): $a$, primary papilla, male paratype, $1.10 \mathrm{~mm}$ HWE (WAM T42558); $b$, primary papilla, female, paratype, $1.25 \mathrm{~mm}$ HWE (WAM T42558); $c$, crural papilla oncopod 1, male, paratype, $1.10 \mathrm{~mm}$ HWE (WAM T42558), arrow indicates foramen; $d$, crural papilla oncopod 3, male, paratype, $1.10 \mathrm{~mm}$ HWE (WAM T42558); $e$, crural papilla oncopod 7, male paratype, $1.10 \mathrm{~mm}$ HWE (WAM T42558), some exudate can be seen protruding from foramen; $f$, crural papilla oncopod 12, male paratype, $1.10 \mathrm{~mm}$ HWE (WAM T42558), arrow indicates foramen (partly obscured by crural gland exudate). Scale bars $100 \mu \mathrm{m}$. 
distal foot papillae and 1-2 bristles on median foot papillae. Distal foot papillae on remaining oncopods each with single sensory bristle.

\section{Male reproductive tract}

Proximal vasa efferentia lying close together, parallel for part of their length before fusing to form vas deferens; broad; vas deferens continues anteriorly from paired vasa efferentia for short distance before looping posteriorly toward gonopore, or loops posteriorly immediately following junction of paired vasa efferentia toward gonopore.

\section{Male glands and gland papillae}

Crural papillae protrude between third (proximal-most) spinous pad and adjacent plicae (oncopod 1), or between plicae 3-4 (counting from third spinous pad) on oncopods 2-14. Papillae shape differs among oncopods: papillae semicircular proximally, cylindrical, taper distally (oncopod 1) (Figure 10c), or broad based, semicircular proximally, abruptly tapered, conical distally on oncopods 2-14 (Figure 10d-f); with finely ribbed scales basally, smooth distally, papillar scales and microcristae fused completely at base of smooth region, only partially fused at distal tips giving knobbly appearance (most obvious on crural papilla on oncopod 1) (Figure 10c-f); crural papillae open via short transverse slit at base of smooth region (oncopod 1), or a via a long transverse slit on basal half of smooth region (oncopods 2-14); foramen openings on inner side of papillae. Crural glands oncopods 1 extending length of body posteriorly to oncopods 12-13. Anterior accessory glands extending anteriorly approximately to oncopods $10-11$.

\section{Remarks}

One male with tan ground colour has regular mottling consisting of a broad tan band dorsally, flanked by dark grey bands laterally and a narrow grey band along midline. One specimen (QM S29906) has distinctive tan bands dorsal to the oncopods.

Females collected in March, April and October contained embryos in the oviducts and many juveniles were found when specimens were collected in April 2000.

Kumbadjena kaata differs from other members of the genus in two characters: the dorsal body patterning, and the shape of the distal tip of the crural papillae on the first pair of oncopods in males. Specimens are easy to find in the Porongurup National Park and there is a good deal of suitable timber on the ground for onychophorans to inhabit. They would seem to be common in the Porongurups Range.

\section{Habitat}

Specimens were found in rotting logs and leaf litter. Hand collected specimens were usually lying flat and straight when first exposed, or with the anterior half of body curved, and head partially tucked in loop of body.

\section{Distribution}

Western Australia, Porongurup NP, approximately $34^{\circ} 39^{\prime} \mathrm{S} ; 117^{\circ} 51^{\prime} \mathrm{E}-34^{\circ} 41^{\prime} \mathrm{S} ; 117^{\circ} 52^{\prime} \mathrm{E}$ (Figure 8).

\section{Etymology}

The specific name is derived from the word 'kaat', meaning 'hill' or 'mountain' in the Nyungar dialect, a language spoken by the Aboriginal people of the south-west of Western Australia (Dench, 1999). It refers to the range of hills in which this species is found.

\section{Kumbadjena shannonensis sp. nov.}

Figures $1 ; 8 ; 11 \mathrm{a}, \mathrm{b} ; 12$

\section{Material examined}

\section{Holotype}

ot Western Australia, Shannon NP, Giant Karri Grove, Deeside Coast Rd, $5 \mathrm{~km} S$ of intersection of Middleton Rd and Deeside Coast Rd, $34^{\circ} 38^{\prime} \mathrm{S}$; $116^{\circ} 20^{\prime} \mathrm{E}, 150 \mathrm{~m}, 8$ Apr 2000, coll. A. Reid and R. Roberts (WAM T42559).

\section{Paratypes}

$120^{*}, 109,6$ juv. data as for holotype (WAM T42560).

\section{Other material examined}

Western Australia: $2 q$, Shannon NP, Fish Ck Rd, 34 37.5'S; $116^{\circ} 26.2^{\prime}$ E, 27 Jan 1999, coll. S. L. Judd (WAM T40864); $1 \delta^{\circ}$, Shannon HP 81, Sutton Block, 16 Nov 1971, coll. J. A. Springett (WAM 76/12); 10 , 1 juv., Dog Pool on Shannon River, $34^{\circ} 46^{\prime} S$; $116^{\circ} 22^{\prime} \mathrm{E}, 27-30$ Apr 1990, coll. M. S. Harvey and J. M. Waldock (WAM 91/1130-1); 19, Dog Pool on Shannon River, $34^{\circ} 46^{\prime} S$; $116^{\circ} 22^{\prime} \mathrm{E}$, 27-30 Apr 1990, coll. M. S. Harvey and J. M. Waldock (WAM 91/ 1129); $1 \delta^{\circ}$, Dog Pool on Shannon River, $34^{\circ} 46^{\prime} \mathrm{S}$; $116^{\circ} 22^{\prime} \mathrm{E}, 27$ Apr-1 May 1990, coll. M. S. Harvey and J. M. Waldock (WAM 91/1132).

\section{Diagnosis}

Usually with dark brown papilla on each side of midline dorsal to each oncopod pair surrounded by squarish light-coloured patch. Some specimens distinctly patterned. Crural papillae with finely ribbed scales basally, crenulated distally, papillar scales and microcristae partially fused, smooth. 

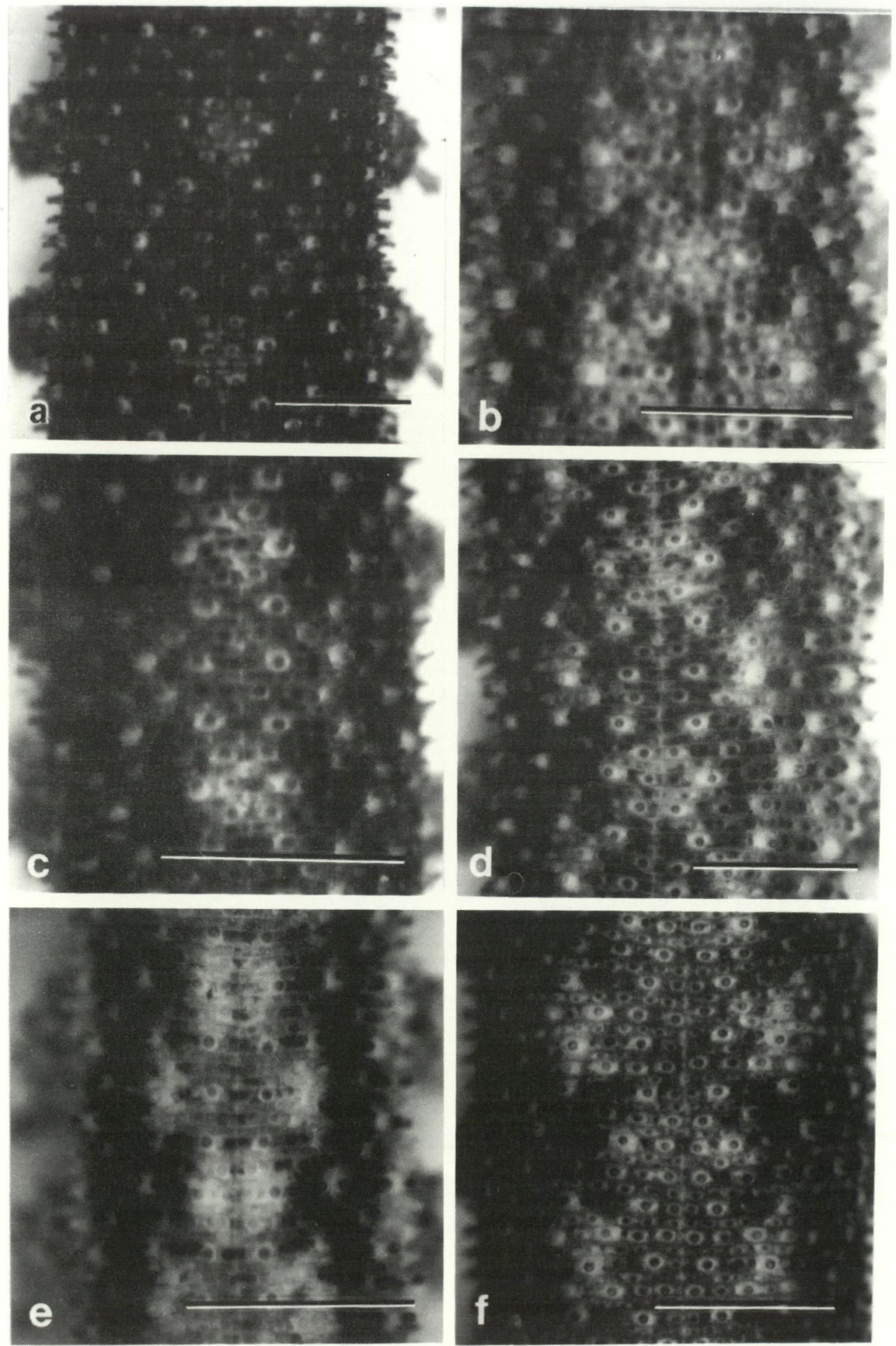

Figure 11 Dorsal integument: $a$, Kumbadjena shannonensis sp. nov., female paratype 1.12 mm HWE (WAM T42560); $b$, K. shannonensis sp. nov., male paratype $0.92 \mathrm{~mm}$ HWE (WAM T42560); c, Mt Chudalup, male $0.95 \mathrm{~mm}$ HWE (WAM T42567); d, Walpole Nornalup NP, female 1.20 mm HWE (WAM T42568); $e$, William Bay NP, female 0.87 mm HWE (WAM T42573); f, West Cape Howe NP, female 1.20 mm HWE (WAM T42574). Scale bars 1.0 $\mathrm{mm}$.

\section{Description}

\section{Measurements}

HWE males 0.92-1.00-1.12 mm ( $\mathrm{n}=13$, holotype $1.00 \mathrm{~mm}$ HWE); females 0.97-1.07-1.12 mm.

\section{Colour pattern}

Ground colour tan, buff brown, olive green, grey, or greyish-blue; primary papillae light-coloured basally, dark tipped. Dark brown papilla usually present on each side of dorsal midline dorsal to 
each oncopod pair (18 of 24 specimens) surrounded by squarish light coloured patch (Figure 11a) (light coloured patch indistinct or absent in dark groundcolour specimens); remaining integument with evenly scattered tan or tan-based papillae, or additional light ground-coloured patches dorsolaterally between median light coloured patches (Figure 11b); light coloured patches bordered by dark pigment (except in dark ground colour specimens). Laterally with longitudinal lightcoloured band dorsal to oncopods. Papillae around anal opening pigmented as for rest of body, or tan. Spinous pads pale yellow or greyish-blue.
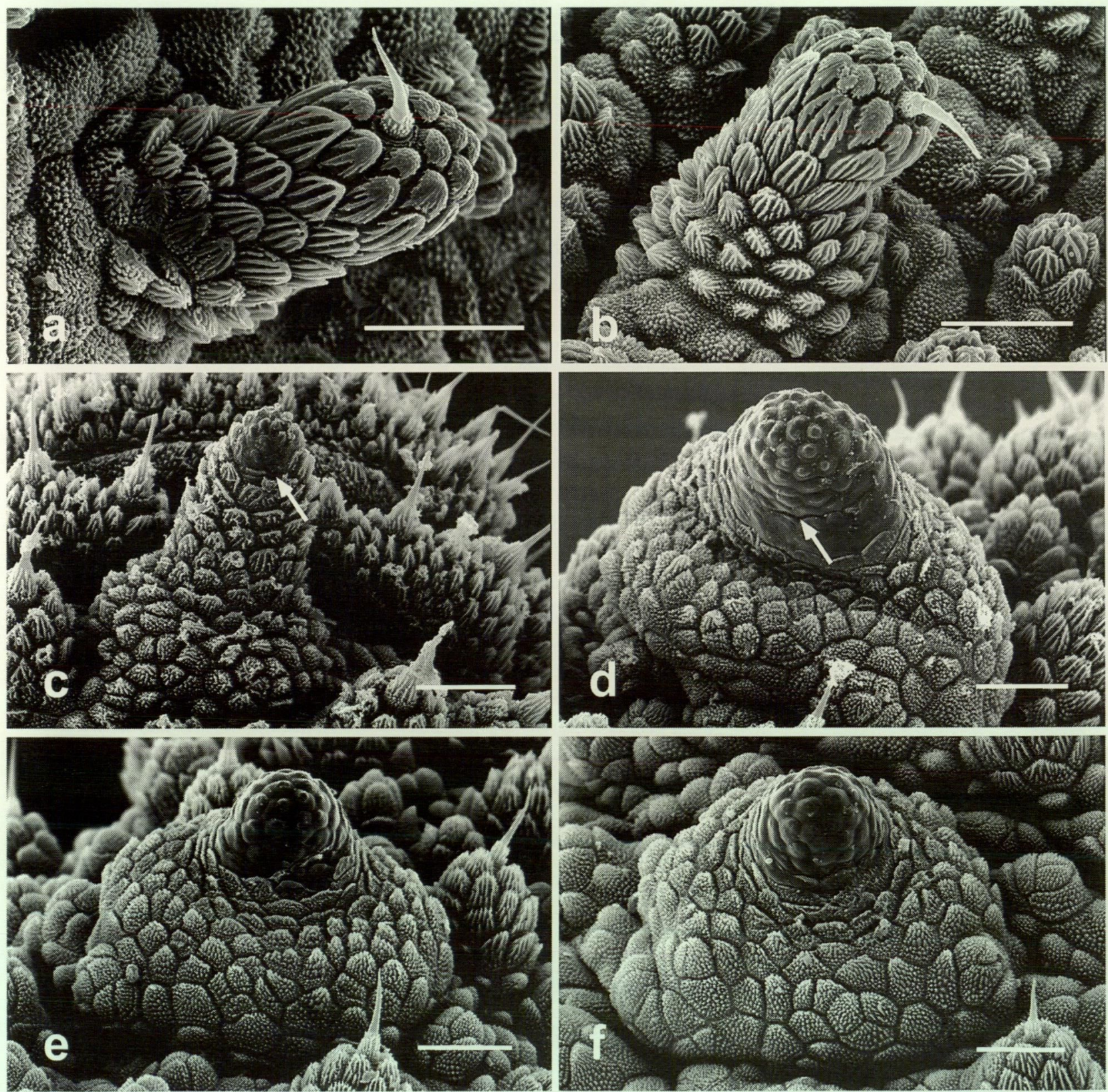

Figure 12 Kumbadjena shannonensis sp. nov. (SEM's): a, primary papilla, male paratype, 1.00 mm HWE (WAM T42560); $b$, primary papilla, female paratype, $1.12 \mathrm{~mm}$ HWE (WAM T42560); $c$, crural papilla oncopod 1, male paratype, $1.12 \mathrm{~mm}$ HWE (WAM T42560), arrow indicates foramen; $d$, crural papilla oncopod 3, male paratype, $1.00 \mathrm{~mm}$ HWE (WAM T42560), arrow indicates foramen; $e$, crural papilla oncopod 7, male, paratype, $1.00 \mathrm{~mm}$ HWE (WAM T42560); f, crural papilla oncopod 12, male paratype, $1.00 \mathrm{~mm}$ HWE (WAM T42560). Scale bars $100 \mu \mathrm{m}$. 
Eyes

EDI males 0.07-0.10-0.12; females 0.07-0.10-0.12.

\section{Integument}

Males with 10-13-15 papillae counted from middorsal line to junction of oncopod 10, females with 12-15-20 papillae counted from mid-dorsal line to junction of oncopod 10. Papillar scales ribbed proximally, smooth distally (microcristae fused) in both sexes (Figure 12a,b).

\section{Oncopods}

Males with two bristles on anterior distal foot papillae oncopod one; 1-3 bristles on posterior distal foot papillae and 2-3 bristles on median foot papillae oncopod one. Distal foot papillae each with single sensory bristle on remaining oncopods.

\section{Male reproductive tract}

Proximal vasa efferentia lying close together, parallel for part of their length before fusing to form vas deferens, or separate, do not lie parallel for part of their length before fusing to form vas deferens; not markedly broad; vas deferens continues directly (without looping posteriorly) from paired vasa efferentia to gonopore.
Male glands and gland papillae

Crural papillae greatly reduced on oncopods 14 . Papillae shape differs among oncopods: papillae semicircular proximally; cylindrical, taper distally (oncopod 1) (Figure 12c), or broad based, semicircular proximally, abruptly tapered, conical, blunt distally on oncopods 2-14 (Figure 12d-f); with finely ribbed scales basally, crenulated distally, papillar scales and microcristae partially fused, smooth. Crural papillae open via a short transverse slit at base of smooth region (oncopod 1) (Figure 12c), or via a long transverse slit on basal half of smooth region (oncopods 2-14); foramen openings on inner side of papillae (Figure $12 \mathrm{~d}-\mathrm{f}$ ). Anterior accessory glands extending anteriorly approximately to oncopods 9-11.

\section{Remarks}

The second pair of feet in males are enlarged, but not to the extent of the first pair of feet. Some juveniles have enlarged feet on the first pair of oncopods. It is likely they are males; they were too small to dissect to confirm this. Some of the preserved males collected in April 2000 had extruded material extending in a thick thread from the anterior accessory glands. Some of the females collected at this time contained well-developed
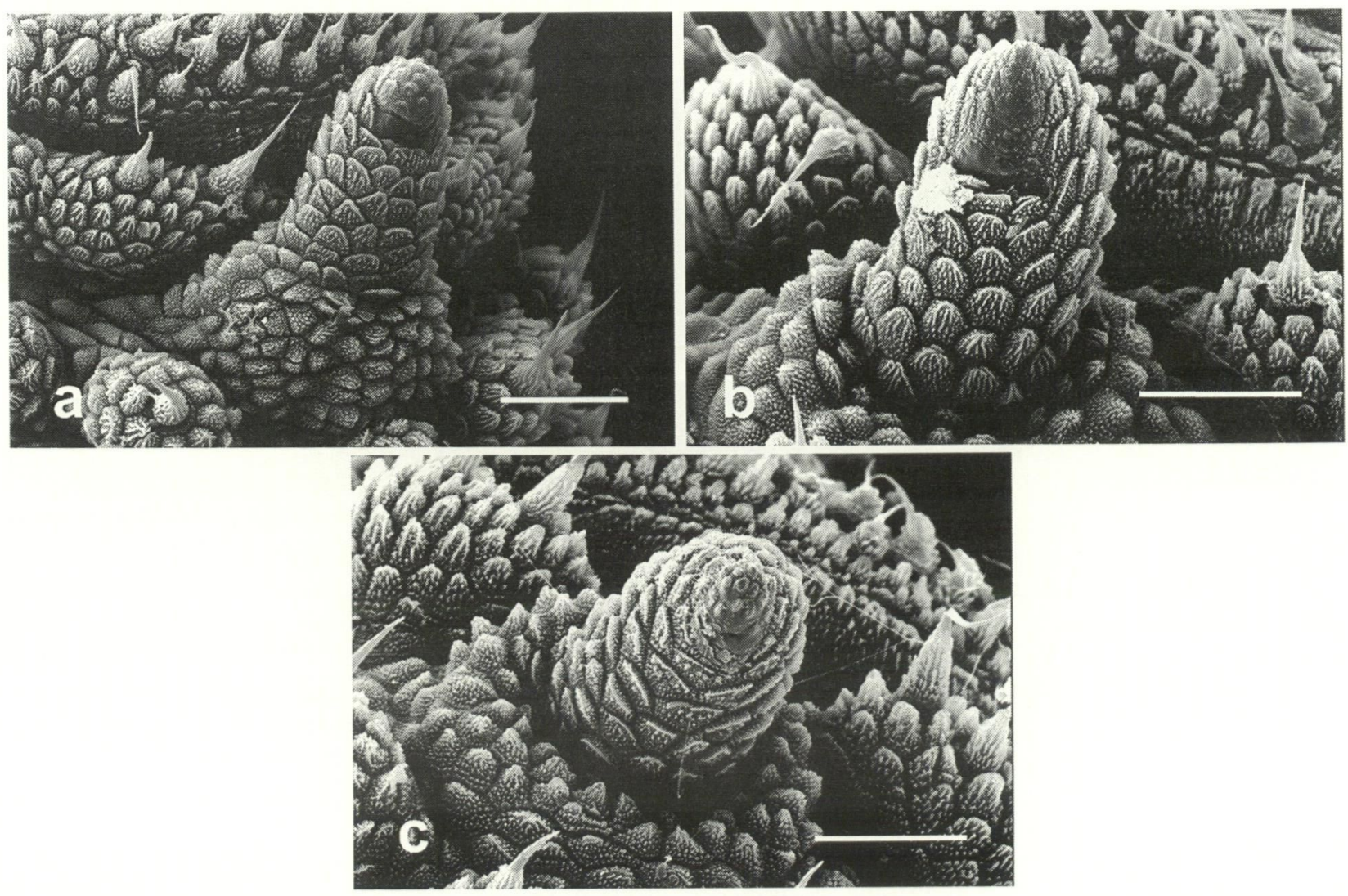

Figure 13 Crural papilla on oncopod 1 in males (SEM's): $a$, Mt Chudalup, 1.00 mm HWE (WAM T42567); $b$, Walpole Nornalup NP, $1.15 \mathrm{~mm}$ HWE (WAM T42568); c, West Cape Howe NP, $1.00 \mathrm{~mm}$ HWE (WAM T42574). Scale bars $a, 200 \mu \mathrm{m} ; b, c, 100 \mu \mathrm{m}$. 
embryos in uteri and large numbers of juveniles were found at the site.

Specimens from the following localities have crural papillae on the first pair of oncopods that are similar to those in this species (smooth distally, with microcristae partially fused) (Figure 13): $\mathrm{Mt}$ Chudalup (WAM T42567), Walpole Nornalup National Park (WAM T42568), William Bay National Park (WAM T42573) and West Cape Howe National Park (WAM T42574). When patterned, these populations show some similarities to and some differences from patterned $K$. shannonensis (for example the squarish light-coloured patch) (compare Figure 11a,b with 11c-f). Until other (possibly molecular) characters are examined, specimens from these localities are not assigned to $K$. shannonensis, however, the similarities suggest they may be closely related to this species.

\section{Habitat}

Leaf litter and under bark, under moss on logs, in logs. Hand collected specimens were usually lying flat and straight when first exposed.

\section{Distribution}

Western Australia, Shannon National Park from Fish Creek Rd, $34^{\circ} 37.5^{\prime} S ; 116^{\circ} 26.2^{\prime} E$ to Dog Pool on Shannon River, $34^{\circ} 46^{\prime} \mathrm{S} ; 116^{\circ} 22^{\prime} \mathrm{E}$ (Figure 8).

\section{Etymology}

The specific name is derived from the type locality of this species, Shannon National Park.

\section{Occiperipatoides Ruhberg Table 1}

Occiperipatoides Ruhberg, 1985 (in part): 123-124, figures $100 \mathrm{~g}, 132$; table 1; Reid, 1996 (in part): 813-814, figure 30 .

\section{Type species}

Peripatoides gilesii Spencer, 1909, by original designation.

\section{Diagnosis}

Dorsal primary papillae with ribbed scales in both sexes (microcristae not fused). Sixteen oncopod pairs; first pair of oncopod feet not enlarged. Crural papillae on oncopod 1 protrude between plicae 2-3 (counting from the third spinous pad). Crural papillae oncopods 2-15 moderately broad basally, cylindrical, elongate distally, blunt; papillar scales and scale microcristae fused, or partially fused, smooth. Crural papillae open distally (oncopods 13), smooth rim surrounding foramen lip-shaped; crural papillae foramen a transverse slit opening on inner side of smooth region (oncopods 6-15). Crural glands extending length of body from first pair of oncopods posteriorly to oncopods 10 or 11 . Posterior accessory gland foramen separate; posterior accessory glands broad and saccate. Ovoviviparous, ova follicular.

\section{Occiperipatoides gilesii (Spencer)}

Figures 14-16

Peripatoides gilesii Spencer, 1909: 420-422; Dakin, 1914a: 289-292, text figure 1; Dakin, 1914b: 3-5.

Peripatoides woodwardi Bouvier, 1909: 315-328, figures $1-5$.

Peripatoides occidentalis var. gilesii Dakin, 1920: 367389 , plates $I-V$, figures $1-25$ (in part).

Occiperipatoides gilesii Ruhberg, 1985: 124-126, figure 109b; Tait et al., 1990: 153-171, table 1; Briscoe and Tait, 1995: 91-102, tables 1 and 3; Reid, 1996: 814-817, figures 93-97.

\section{Material examined}

\section{Syntypes}

Western Australia: Peripatoides gilesii 4? (dehydrated, sex unknown), Armadale, 32\%09's; $116^{\circ} 00^{\prime} \mathrm{E}, 26$ Mar 1907, coll. H. M. Giles (MV); Peripatoides woodwardi of Lion Mill (near Perth) [Mt Helena $31^{\circ} 13^{\prime} 54^{\prime \prime} S$; $\left.115^{\circ} 54^{\prime} 00^{\prime \prime} \mathrm{E}\right], 1905$, coll. W. Michaelsen (Paris Boc7 and ON 29); $q$, data as for previous specimen, 20 Aug 1905, coll. Hambg SW Aust. exp. (BMNH).

\section{Other material examined}

Western Australia: $1 \delta^{*}$ Yanchep NP, unnamed cave near Nambibby Cave, $21^{\circ} 31^{\prime} S$; $115^{\circ} 41^{\prime} \mathrm{E}, 9$ Aug 1981, coll. M. Newton (WAM 91/1122); 1 \% Yanchep NP, Coral Cave YN-128, 31 31'S; $115^{\circ} 41^{\prime} \mathrm{E}, 5$ Dec 1998, coll. R. Foulds (WAM 99/249); 2\%, Yanchep NP, $31^{\circ} 31^{\prime} S ; 1^{\circ} 41^{\prime} \mathrm{E}, 21$ Sep 1984, coll. M. Bezant, S. Elliot and M. Newton (WAM 91/ 1123-4); $1 \delta$, Yanchep NP, $31^{\circ} 31^{\prime} S ; 115^{\circ} 41^{\prime} \mathrm{E}, 25 \mathrm{Jul}$ 1998, coll. R. Foulds (WAM 99/248); 16 , Carabooda area, Peripatus Cave $\mathrm{YN}-484,31^{\circ} 36^{\prime} \mathrm{S} ; 115^{\circ} 43^{\prime} \mathrm{E}, 20$ Jun 1996, coll. R. Foulds (WAM 99/247); 1 \%, Carabooda area, unnamed cave, $31^{\circ} 36^{\prime} \mathrm{S}$; $115^{\circ} 43^{\prime} \mathrm{E}$, 19 Jan 1999, coll. R. Foulds (WAM 99/250); 19 , Carabooda area, Carabooda Cave, YN-474, 31 ${ }^{\circ} 37^{\prime} \mathrm{S}$; $115^{\circ} 43^{\prime} \mathrm{E}, 9$ May 1998 , coll. R. Foulds et al. (WAM T40856); 29 , Mt Helena, 31 ${ }^{\circ} 52^{\prime} \mathrm{S} ; 116^{\circ} 12^{\prime} \mathrm{E}, 28 \mathrm{Jul}$ 1927, coll. C. F. Mattram (WAM 95/525-6); 1\%, Darlington, $31^{\circ} 54^{\prime} \mathrm{S} ; 1^{\circ} 16^{\circ} 05^{\prime} \mathrm{E}$, Aug 1963, coll. B. Rudeforth (WAM 97/2563); 13ð, $3 \%$, Mundaring $31^{\circ} 54^{\prime} \mathrm{S}$; $116^{\circ} 10^{\prime} \mathrm{E}, 6$ Nov 1926, coll. J. Clark (AM KS40116); $10^{\circ}, 1$ \% , Sawyers Valley, 31 $54^{\prime}$ 'S; $116^{\circ} 12^{\prime} \mathrm{E}$, 21 Jul 1966, coll. R. Woodward (WAM 76/10-1); 19. Darlington, $31^{\circ} 55^{\prime} S ; 116^{\circ} 04^{\prime} \mathrm{E}$, Aug 1965, coll. R. P. McMillan (WAM 97/2564); 1 , , locality as for previous specimen, 21 Jun 1988, coll. B. Rudeforth (AM KS40070); 1', Darlington, $31^{\circ} 55^{\prime} \mathrm{S} ; 116^{\circ} 04^{\prime} \mathrm{E}$, 

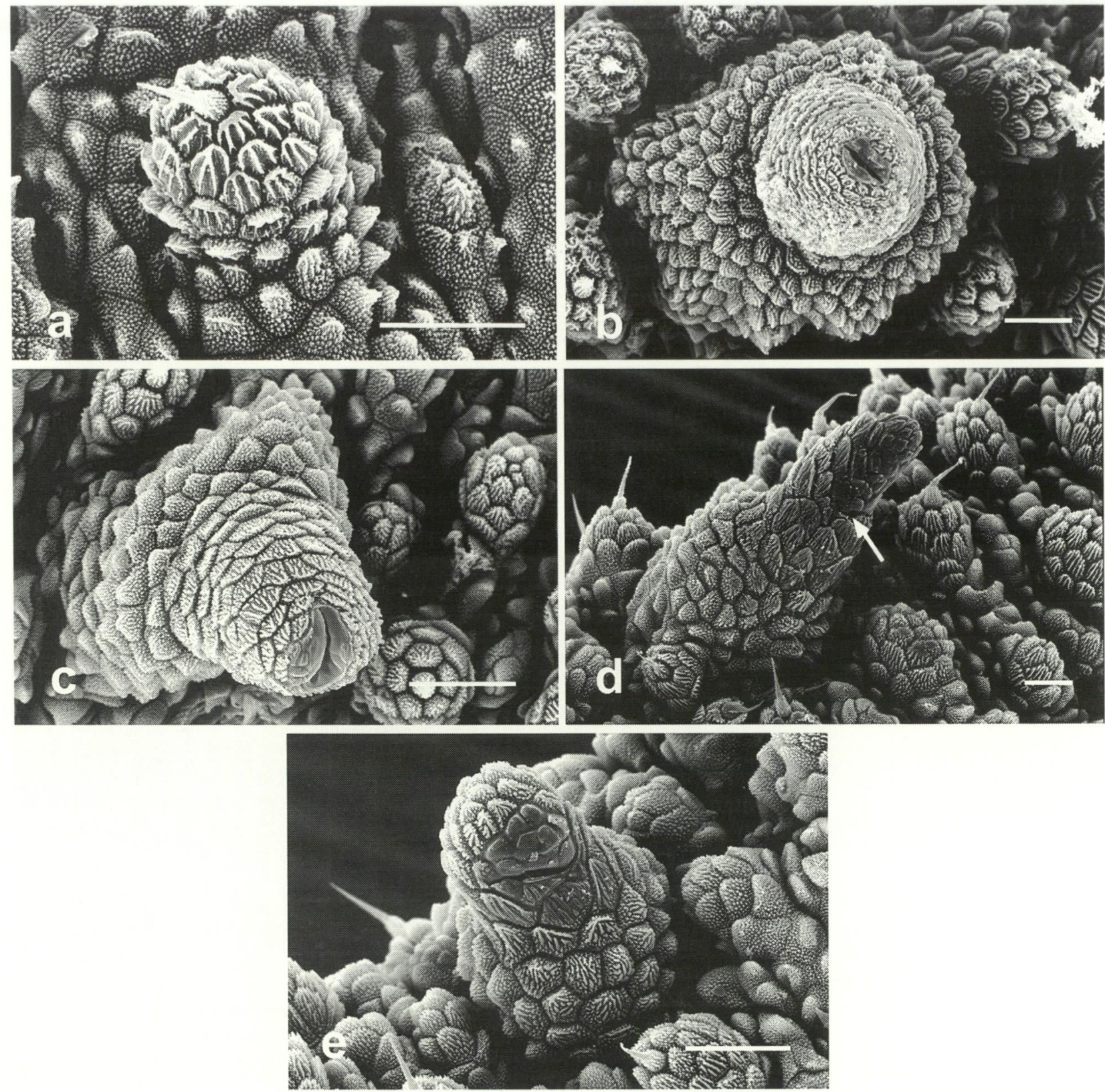

Figure 14 Occiperipatoides gilesii (Spencer) (SEM's): $a$, primary papilla; $b$, crural papilla oncopod $1 ; c$, crural papilla oncopod 3; $d$, crural papilla oncopod 7, arrow indicates foramen; $e$, crural papilla oncopod 13. $a-e$, male 1.20 mm HWE, Pickering Brook, Kattororcia Heritage Trail, 3202'S; $116^{\circ} 06^{\prime} \mathrm{E}$ (unregistered specimen). Scale bars $100 \mu \mathrm{m}$.

Sep 1974, coll. G. H. Lowe (WAM 76/13); 1 \& , Hay Creek, Mundaring Weir, 31 $58^{\prime} \mathrm{S} ; 116^{\circ} 10^{\prime} \mathrm{E}, 19 \mathrm{Jul}$ 1914, coll. W. B. Alexander (WAM 14/985); $10^{\circ}$, Kalamunda, $31^{\circ} 58^{\prime} \mathrm{S}$; $116^{\circ} 03^{\prime} \mathrm{E}$, Jun 1962 , coll. R. P. McMillan (WAM 97/2566); 19, Lesmurdie, $32^{\circ} 01^{\prime}$ S; $116^{\circ} 03^{\prime} \mathrm{E}$, Jul 1963, coll. R. P. Mc Millan (WAM 91/1115); $1 \delta^{\star}$, data as for previous specimen (WAM 91/1116); 20, Darlington Ranges, Pickering Brook, Kattororcia Heritage Trail, $32^{\circ} 02^{\prime}$ '; $116^{\circ} 06^{\prime} \mathrm{E}$, coll. P. T. Bailey (WAM); $40^{\star} 3$ \% , Jandakot $32^{\circ} 07^{\prime}$ '; 11550'E, 7 Mar 1991, coll. S. Doyle (AM KS40071);

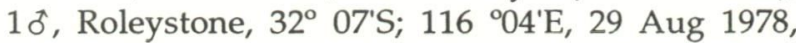
coll. D. Burtenshaw (WAM 91/1119); 1 \% , Mt Dale,
W side of, $32^{\circ} 07^{\prime} S$; $116^{\circ} 18^{\prime} \mathrm{E}, 29$ Sep 1997, coll. S. Slack-Smith and J. M. Waldock (WAM 99/246); $19,3 \mathrm{~km}$ NE of Jarrahdale, $32^{\circ} 09^{\prime} \mathrm{S} ; 1^{\circ} 16^{\circ} 05^{\prime} \mathrm{E}, 9 \mathrm{Nov}$ 1995, coll. O. G. Nicholls (WAM 97/2565); 1 ㅇ, Gleneagle, 32 $2^{\circ} 15^{\prime} S ; 116^{\circ} 10^{\prime} \mathrm{E}$, 22 Sep 1971, coll. J. A. Springett (WAM 76/7); 1 \%, Jarrahdale, Alcoa mine site, 32¹9'S; $113^{\circ} 59^{\prime} \mathrm{E}$, 1997, coll. K. E. C. Brennan (WAM T40857); 19 , Gleneagle, 32¹9'S; $116^{\circ} 11 ' \mathrm{E}, 22$ Oct 1971, coll. J. A. Springett (WAM 76/7); 1 ㅇ, near Gleneagle, $10 \mathrm{~km} \mathrm{ENE} \mathrm{of}$ Jarrahdale, $32^{\circ} 19^{\prime} S$; $116^{\circ} 11$ 'E, 14 Aug 1992, coll. O. Nicholls (WAM 95/484); 39 , Serpentine, 32²2'S; 11558'E, 28 Aug 1928, coll. L. Glauert (WAM 
13713-5); $1 \delta, 1$, , Serpentine R., $\sim 32^{\circ} 23^{\prime} \mathrm{S} ; 116^{\circ} 00^{\prime} \mathrm{E}$ (WAM 91/1120-1); 19, Serpentine Falls, 27 Jul 1969, coll. S. Slack-Smith (WAM 76/6); 19, Karnet Brook, 32 $24.4^{\prime} \mathrm{S}$; $116^{\circ} 01.6^{\prime} \mathrm{E}, 29$ Jul 1998, coll. S. L. Judd (WAM T40858); 2 ', Mt Cooke, 32 $25^{\prime}$ 'S; $116^{\circ} 18^{\prime} \mathrm{E}, 30$ Jun 1991, coll. J. M. Waldock (WAM $91 / 1117-8) ; 19$, locality as for previous specimen, 20 Jun 1992, coll. D. Black (AM KS40072); 29 locality as for previous specimens, 31 Jul 1991, coll. M. S. Harvey and J. M. Waldock (WAM 95/487488); 2\%, Escarpment between Whittakers Mill and North Dandalup, 32 $33^{\circ} \mathrm{S} ; 1^{\circ} 6^{\circ} 00^{\prime} \mathrm{E}, 15$ Jun 1969, coll. S. Slack-Smith (WAM 76/2-3); 19 , Whittaker Forest Block, Scarp Rd, 32³3.6'S; 116 00.3'E, 29 Jul 1998, coll. S. L. Judd (WAM T40865); 2क, $31 \mathrm{~km} \mathrm{NE}$ Dwellingup (North East Rd), 32 $43^{\prime} S ; 116^{\circ} 04^{\prime} \mathrm{E}, 21$ Jun 1992, coll. D. Black (AM KS40117); 1 \%, Dwellingup, Young Block, 32 $43^{\prime} \mathrm{S} ; 116^{\circ} 02^{\prime} \mathrm{E}$, Apr 1980, coll. I. Abbott (WAM 91/1112); 1F, $3 \mathrm{~km} \mathrm{NE}$

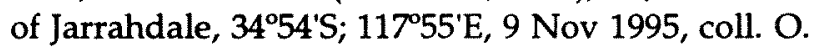
G. Nicholls (WAM 97/2565); 19, Jarrahdale, $34^{\circ} 54^{\prime} \mathrm{S} ; 117^{\circ} 55^{\prime} \mathrm{E}$ (WAM 91/1113); $1 \delta^{\circ}, 13.8 \mathrm{~km}$ NNE of Jarrahdale, adjacent to McAllister Rd, 1.2 km from Albany Hwy, 6 Jul 1994, coll. F. Nichols (WAM 95/485); 1 \% , John Forrest NP, Sep 1976, coll. G. H. Lowe (WAM 91/1114).

\section{Diagnosis}

As for genus.

\section{Description}

\section{Measurements}

HWE males 1.08-1.29-1.40 mm; females $1.26-$ 1.41-1.53 $\mathrm{mm}$.

\section{Colour pattern}

Body pigmented. Pigment not soluble in alcohol. Body patterned; ground-colour tan or greyish-blue; primary papillae light-coloured basally, dark tipped (some papillae tan-based with dark brown or grey apices). Mid-dorsal dark stripe absent; every fourth plica with transverse row of dark grey papillae, rows of four (two each side of mid-dorsal line) alternate with two (one each side of mid-dorsal line); remaining integument with regular tan and dark mottle, or very dark grey specimens with scattered tan, or tan-based papillae. Predominantly tan specimens with grey mottle, every 4 th plica with two dark grey plicae (one each side of midline) and longitudinal greyish bands dorsal to oncopods. Some specimens with head anterior to eyes and base of antennae $\tan$ (WAM T40856, WAM 99/ 250, WAM 99/249 (all from caves in the Yanchep National Park) and WAM 95/488 from Mt Cooke). Laterally with longitudinal light-coloured band dorsal to oncopods, or without pattern, colour as for rest of body. Oncopods often with light-coloured patches close to body (pale yellow), or primarily greyish blue; without lightcoloured patches at junction with feet. Papillae around anal opening pigmented as for rest of body. Ventral pigment mainly absent; with few scattered greyish-blue papillae. Spinous pads pale yellow or greyish-blue. Integument between genital and anal openings pigmented as for rest of ventrum, or darker than rest of ventrum.

Antennal rings banded, $\tan$, or with $\tan$ mottle dorsally; dorsal banding on proximal half of each antennal ring (distal half ground-colour) for half antennal length.

\section{Antennae}

Approximately 30 antennal rings in adults and juveniles; wide and narrower antennal rings alternate; two rows of bristles on rings (counting from distal to proximal) $3,6,8$ or $3,4,6,8$. Distal 8 9 antennal rings with sensory bulbs. Proximal antennal rings expanded ventrally to form sensory pads; sensory pads with up to two rows of sensilla.

\section{Eyes}

EDI males 0.06-0.08-0.08; females 0.06-0.07-0.08.

\section{Head (males)}

Males with no modification of head papillae (i.e. papillae on head do not differ from remaining dorsal papillae). Eversible head structure absent.

\section{Head (females)}

Females with no modification of head papillae.

Jaws

Inner jaw with five denticles; diastema absent; outer jaw without accessory tooth. Tongue with longitudinal row of five teeth. Buccal folds in single unbroken row.

\section{Integument}

Dorsum with 12 complete plicae between oncopods; wide and narrower plical folds alternate. Males with 14-17-20, females with 15-19-22 papillae counted from mid-dorsal line to junction of oncopod 10. Dorsal body papillae approximately uniform size; alternate plicae with slightly larger primary papillae; primary papilla with short, narrow bristle between pair of larger primary papillae with longer, more robust bristles and smaller secondary papillae between primary papillae; remaining integument with small scales; dorsal primary papillae cylindrical; conical apical piece absent; papillar scales ribbed in both sexes (microcristae well defined) (Figure 14a); lateral primary papillae slightly enlarged or elongate, with more prominent pair between oncopods in line with junction of oncopods and body; papillae around 
anal opening slightly larger than those on rest of body. Ventral organs whitish.

\section{Oncopods}

16 pairs in both sexes. First pair of oncopod feet not enlarged in males, similar in size to remaining feet. Last pair of oncopods well developed in both sexes, orientation as for remaining oncopods. Basal foot papillae absent; distal foot papillae: one anterior, one median, one posterior, each with single sensory bristle. With three complete spinous pads (third spinous pad narrow, often broken), fourth broken spinous pad present. Nephridiopores at centre of third spinous pad on third and fourth oncopod pair; foramen broad, U-shaped.

\section{Male reproductive tract}

Male genital pad low, semicircular; gonopore cruciform (with arms equidistant), arms extending close to rim of genital pad. Vasa efferentia with thin, flexible walls; proximal vasa efferentia separate, do not lie parallel for part of their length or not separate, lie parallel for part of their length before fusing to form vas deferens; broad (Figure 15); vas deferens loops posteriorly at junction of paired vasa efferentia toward gonopore, not thick walled, opaque, not shiny. Spermatophore pouch absent.

\section{Male glands and gland papillae}

Crural papillae, one per oncopod, present on ventral side of oncopods 1-15; protrude between plicae 2-3 (counting from third spinous pad) (oncopod 1), and protrude between plicae 5-6 on oncopods 2-15. Papillae differ in shape and nature of opening: oncopods 1-3 papillae broad basally, taper abruptly, cylindrical, blunt distally with finely ribbed scales basally, distally scales with distinct ribs; smooth region surrounding distal foramen wide, lip-shaped, positioned distally (Figure 14b,c); foramen oncopods 4-5 displaced dorsolaterally; oncopods 6-15 crural papillae cylindrical, tapered gradually, narrow, elongate distally, blunt with finely ribbed scales, or scales smooth, microcristae fused on distal scales; smooth region surrounding mediolateral slit-like foramen (Figure 14d,e) not strongly demarked from rest of papilla, scales fused, smooth or slightly crenulated to distal tip of papilla. Crural glands extend into lateral haemocoel from oncopod 1, or do not extend into lateral haemocoel, confined to oncopods (oncopods 2-15); glands extending from oncopod 1 straight, extend length of body posteriorly to oncopods 10 or 11 . Coxal organs absent. Anterior accessory gland papillae do not protrude significantly, with illdefined margins, without smooth distal region; foramen a longitudinal slit; anterior accessory glands present; moderate length; lying freely within perivisceral haemocoel, extending anteriorly to

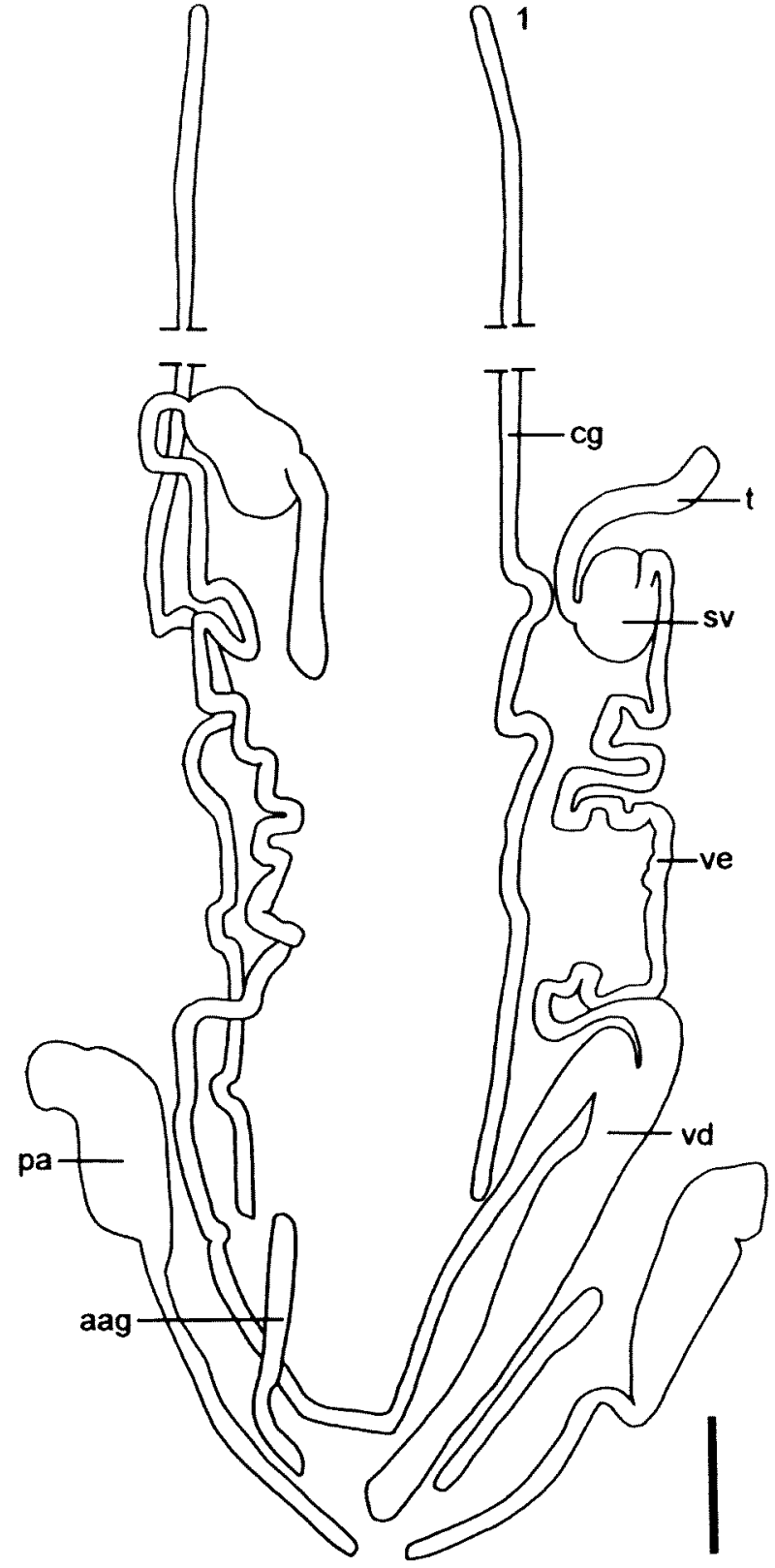

Figure 15 Occiperipatoides gilesii (Spencer). Male reproductive tract and associated glands: $1.26 \mathrm{~mm}$ HWE (AM KS40071); aag, anterior accessory gland; $\mathrm{cg}$, crural gland; $\mathrm{pa}$, posterior accessory gland; sv, seminal vesicle; $t$, testis; vd, vas deferens; ve, vas efferens. Number 1 refers to the position of the corresponding oncopods. Scale bar $1 \mathrm{~mm}$. (Figure redrawn from Reid, 1996, fig. 94: 817.)

oncopods 14 or 15; glands opaque, silvery, shiny. Posterior accessory glands present; foramen approximately midway between genital and anal openings; gland foramen separate; glands broad and saccate; blunt distally, sometimes, truncate distal knob (Figure 15).

\section{Female reproductive tract}

Females without ovipositor; ovoviviparous; 


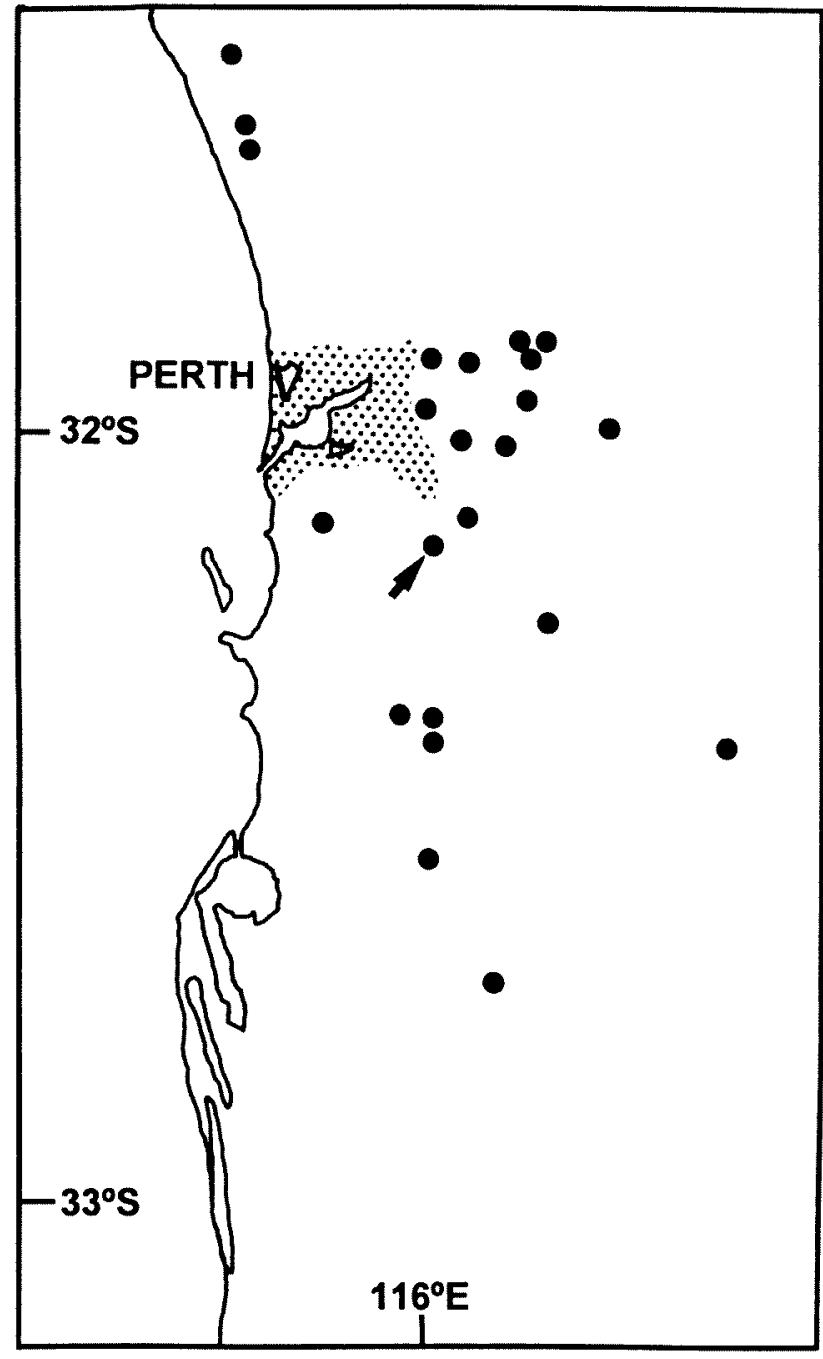

Figure 16 Distribution of O. gilesii (Spencer), solid circles. Arrow indicates the type locality. Geographical position of this region is indicated by the upper shaded region (arrowed) on the insert map of Australia in Figure 8.

gonopore not borne on raised pad; foramen shape cruciform, (with arms equidistant). Ovarian tubes separate, suspended along entire length to pericardial floor; with thin walls; oviducts unite close to ovary, ova follicular. Spermathecae present, open into oviduct via single duct. Additional pouches present.

\section{Female glands and gland papillae}

Crural papillae absent (see Remarks, Kumbadjena occidentalis). Uterine glands absent.

\section{Remarks}

Ruhberg (1985) erected the genus Occiperipatoides to distinguish the Western Australian species, $O$. gilesii and O. occidentalis, from the eastern Australian Euperipatoides and Peripatoides from New Zealand.

Reexamination of $O$. gilesii and $O$. occidentalis has led to the placement of these taxa (the latter comprising a species-complex) in two separate genera. Their differences are listed under the diagnoses for each genus and in Table 1.

None of the females examined contained welldeveloped embryos in the oviducts, though most contained yolky eggs, some of which were quite large. This could be because the females examined were collected predominantly between JuneNovember. Van Der Lande (1978) observed welldeveloped embryos in females killed and dissected in January, with juveniles born in March-April.

\section{Habitat}

Leaf litter and under logs and stones. The specimen from an unnamed cave in the Carabooda area was collected 'off moonmilk on rock in the dark zone' (WAM 99/250 specimen label).

\section{Distribution}

Western Australia: from Yanchep NP, 31 $31^{\prime} \mathrm{S}$; $115^{\circ} 41^{\prime} \mathrm{E}$ to Jarrahdale, $34^{\circ} 54^{\prime} \mathrm{S} ; 117^{\circ} 55^{\prime} \mathrm{E}$ (Figure 16).

\section{DISCUSSION}

\section{Biogeography}

The Western Australia onychophorans inhabit a relatively small region in the south-west corner of the state. Occiperipatoides gilseii is found within the area of the Perth Basin: a long, narrow trough of sediments extending from north of the Murchison River $\left(27^{\circ} 30^{\prime} \mathrm{S} ; 115^{\circ} 00^{\prime} \mathrm{E}\right)$ to the south coast. Kumbadjena spp. are distributed further south, with a west-east range approximately from the Leeuwin Naturaliste National Park ( $\left.34^{\circ} 06^{\prime} \mathrm{S} ; 115^{\circ} 03^{\prime} \mathrm{E}\right)$ to Two People's Bay (34⒌'S; $\left.118^{\circ} 11^{\prime} \mathrm{E}\right)$, with northern outliers occurring south-east of Bunbury and in the Stirling Ranges (Figure 8).

Both genera (like much of the south-western flora and fauna) are endemic to Western Australia, undoubtedly due to the marine, edaphic, or climatic barriers to migration which have occurred since the Eocene. As noted by Hopper (1979: 415), who examined speciation in the flora of south-west Australia, 'these barriers have effectively isolated most components of the flora from related groups in eastern Australia, and have been responsible primarily for the maintenance of high specific endemism in the region'.

The general landscape and vegetation where Occiperipatoides occurs is very different to that where Kumbadjena are found. The region of the Perth Basin has a lower rainfall than areas further south. The primary vegetation types are eucalyptand banksia-dominated woodlands on the leached sands of the Swan Coastal Plain, with jarrah and marri forests on the eastern margins of the range of O. gilesii. 
In contrast (with the exception of a few outliers), most representatives of the $K$. 'occidentalis' group are found in forest dominated by karri (Eucalyptus diversicolor F. Mueller) occurring on lateritic soils (Figure 8). Karri forest requires a relatively high rainfall and is primarily limited to the $1100 \mathrm{~mm}$ isohyet, though other factors, such as soil type, influence the limits of its distribution. The range and frequency of karri has decreased with aridity over the last 5000 years (Churchill, 1968): this appears also to be true for Onychophora, with populations not only found within the main karri forest belt, but within outlying pockets of karri forest (for example in the western Leeuwin Naturaliste National Park and the Porongurups Range).

Because of the commercial importance of karri, its distribution and biology have been well studied, and it is interesting to compare such studies with what is known so far about the Onychophora inhabiting these forests. Coates and Sokolowsi (1989) examined genetic diversity in karri and found relatively low levels of genetic divergence over the main part of the distributional range (the central block extending from near Nannup, $33^{\circ} 59^{\prime} \mathrm{S} ; 115^{\circ} 45^{\prime} \mathrm{E}$, in the north and southeast to Denmark, $34^{\circ} 58^{\prime} \mathrm{S} ; 117^{\circ} 21^{\prime} \mathrm{E}$ ). Clear genetic differentiation was found in populations occurring on coastal limestone to the west (corresponding to the Leeuwin-Naturaliste National Park in the present study), from the Porongurups Range at the far east of the range, and a site at Rocky Gully (east of the main forest block). Interestingly, outlying coastal populations at William Bay and Mt Manypeaks showed insignificant genetic divergence from the main forest. This led Coates and Sokolowski (1989) to postulate that populations on the southern coastal sands appear to have been remained connected with the main forest until relatively recently, while the three clearly differentiated populations listed above probably became isolated at the beginning of the dry period about 5000 B.P.

Of the three clearly differentiated karri populations, I have identified in this paper a morphologically distinct species of Onychophora, $K$. kaata, from the Porongurups Range. No obvious morphological differences could be found between the specimens from the Leeuwin Naturaliste National Park and populations further east. In April 2000 I visited Rocky Gully, but found remnants of karri only on private land and time constraints did not permit a thorough search in the general vicinity.

Species occurring in the main (central) karri forest block, including the outlying coastal populations, are very similar morphologically, though two species of onychophoran, $K$. occidentalis and $K$. shannonensis are recognised.

If we infer from the assumption that morphological and genetic divergence generally increases between species through time, we can assume that the morphologically distinct taxa, Occiperipatoides and Kumbadjena can be regarded as evolutionary relicts, while the species and suspected cryptic species within Kumbadjena are more recently evolved. Perhaps the two genera, Kumbadjena and Occiperipatoides, evolved from a once continuous population that became divided as a result of changes in sea level during the Quaternary when phases of marine transgression and regression opened and closed coastal migration routes and led to the formation of the Swan Coastal Plain. Combined with the results of increased aridity, Occiperipatoides now appears to be physiologically better adapted to less humid microhabitats than Kumbadjena.

It is possible that $K$. kaata from the Porongurups evolved during the Eocene period when a major period of marine transgression occurred. At this time, the sea extended inland to the east of Denmark, creating islands of the Stirling and Porongurups Ranges as well as coastal promontories such as those at West Cape Howe National Park, Torndirrup National Park, and Two People's Bay Wildlife Reserve (McWhae et al., 1958). However, since the other Kumbadjena species can only be regarded as close morphological relatives, the Eocene period seems too remote to account for the evolution of this species. As Coates and Sokolowski (1989) conclude for the genetically distinct karri population in the Porongurups, it is more likely that $K$. kaata evolved following isolation during a more recent dry period.

That Kumbadjena populations are so similar morphologically over a comparatively wide distributional range (relative to onychophoran distribution in eastern Australia), can probably be explained by similar reasons to the lack of genetic diversity in karri over the same area. The large, mostly continuous karri belt in the south has probably persisted as a result of climatic stability (with high rainfall) and the preservation and continued formation of lateritic soils throughout the mid-late Tertiary and Quaternary. Such a stable population structure favours slow evolution and speciation (Hopper, 1979).

\section{Implications for conservation}

The tall forested regions of south-western Western Australia contain a unique assemblage of animals and plants with special conservation significance (Christensen, 1992). These areas of relatively high rainfall have provided a refuge for elements of the old Gondwanan fauna, such as the Onychophora during long epochs of climate change (Hopper et al., 1996). The strong link between Kumbadjena and karri distributions in the south provide a strong impetus for the conservation of the 
karri communities upon which these (and other) animals depend.

While only three species of Kumbadjena have been described, it is suspected that the group comprises a cryptic species complex. This needs to be examined using additional characters, perhaps molecular, and/ or karyology. It is important that such studies are published, that they include decisions regarding species boundaries and formal descriptions, and include the lodgement of reference specimens in museum collections. Recognition of taxa represented only by locality names is a virtually useless exercise as it does not permit any future comparative studies to test species hypotheses. It is also possible that more than one species may occur at a given locality. These are not trivial matters: unless species are formally named, and can be referred to as such, they have little conservation status. Formally named species have higher conservation status on state and federal lists of threatened species in Australia than unnamed taxa. These points are worth mentioning as it is a problem that occurs recurrently in molecular studies.

Given the strong links that have been discovered between karri and onychophoran distributions, it would be valuable to see whether Onychophora can be found within outlying karri populations that have not been explored to date (for example, near the south coast adjacent to Mt Manypeaks; Yallingup; Black Point, east of Albany and Rocky Gully, north-west of Denmark; the Donnybrook Sunklands and the Perup Nature Reserve). Hopper et al. (1996: 36-37) also refer to the interpretation of topography to assist the recognition of potential collecting sites: 'minor changes in altitude and relief provided by remnants of the older land surface, or granite outcrops' and 'seasonally wet places on the old land surface or tops of breakways' are localities likely to contain Gondwanan elements. Onychophorans occupying such remnant pockets may require particular protection. Obviously this would be true if new species are discovered that occur only in isolated pockets. Protection may also be needed for already known species found in outlying isolated populations: these would be important reservoirs of genetic diversity for the species in question. The importance and vulnerability of habitats supporting Gondwanan relicts is discussed by Hopper et al. 1996.

It seems that in contrast to Kumbadjena, Occiperipatoides is represented by a single relatively widespread species. However, this should also be tested using molecular characters, because its extensive distribution is quite unusual for an Australian onychophoran. If all populations are referable to a single species, its status is relatively secure, but should be monitored given its proximity to Perth and potential vulnerability due to the encroachment of urban areas and resultant destruction of suitable habitat.

\section{ACKNOWLEDGEMENTS}

I am very grateful to Bert Roberts for accompanying me on fieldwork conducted in April 2000, and to Joan Clark from the Zoology Department at Melbourne University for help with scanning electron microscopy. I also wish to thank the following people for specimen loans: Dr $\mathrm{M}$. Harvey (WAM), Dr B. Halliday (ANIC), Mr P. Hillyard (BMNH), Dr M. Gray (AM), Dr J.-P. Mauriés (MNHN), Dr R. Raven (QM) and Dr H. Ruhberg (ZMH). Thanks also to the referees for their helpful comments. This work was supported by the Australian Biological Resources Study (Environment Australia).

\section{REFERENCES}

Bouvier, E.L. (1909). Die Fauna Südwest-Australiens: Onychophora. In W. Michaelsen, W. and Hartmeyer R. (eds), Ergebnisse der Hamburger südwest-australischen Forschungsreise 1905, 2(18): 315-328. Verlag von Gustav Fischer, Jena.

Briscoe, D.A. and Tait, N.N. (1995). Allozyme evidence for extensive and ancient radiations in Australian Onychophora. Zoological Journal of the Linnean Society, London 114: 91-102.

Christensen, P. (1992). The Karri Forest: Its conservation, significance and management. Department of Conservation and Land Management, Como, Western Australia.

Churchill, D.M. (1968). The distribution and prehistory of Eucalyptus diversicolor F. Muell., E. marginata Donn ex $\mathrm{Sm}$., and E. calophylla $\mathrm{R} . \mathrm{Br}$. in relation to rainfall. Australian Journal of Botany 16: 125-131.

Coates, D.J. and Sokolowski, R.E. (1989). Geographic patterns of genetic diversity in karri (Eucalyptus diversicolor F. Muell.). Australian Journal of Botany 37: 145-156.

Dakin, W.J. (1914a). Fauna of Western Australia.-I. The Onychophora of Western Australia. Proceedings of the Zoological Society of London XX: 289-292.

Dakin, W.J. (1914b). The Onychophora of Western Australia. Journal of the West Australian Natural History and Science Society 5: 3-5.

Dakin, W.J. (1920). Fauna of Western Australia.-III. Further contributions to the study of Onychophora. The anatomy and systematic position of west Australian Peripatoides, with an account of certain histological details of general importance. Proceedings of the Zoological Society of London 26: 267-389.

Dench, A. (1999). Nyungar. In N. Thieberger and W. McGregor (eds), Macquarie Aboriginal Words: 173-192. The Macquarie Library Pty Ltd, NSW.

Fletcher, J.J. (1895). On the specific identity of the Australian Peripatus usually supposed to be $P$. leuckarti, Saenger. Linnean Society of New South Wales, Proceedings 10 (2nd series): 172-194. 
Gleeson, D.M., Rowell, D.M., Tait, N.N., Briscoe, D.A. and Higgins, A.V. (1998). Phylogenetic relationships among Onychophora from Australia inferred from the mitochondrial cytochrome oxidase subunit I gene. Molecular Phylogenetics and Evolution 10(2): 237-248.

Hopper, S.D. (1979). Biogeographical aspects of speciation in the southwest Australian flora. Anmual Review of Ecology and Systematics 10: 399 422.

Hopper, S.D., Harvey, M.S., Chappill, J.A., Main, A.R. and Main, B.Y. (1996). The Western Australian biota as Gondwanan heritage - a review. In S.D. Hopper et al. (eds), Gondwanan Heritage: past, present and future of the Western Australian biota: 1-46. Surrey Beatty and Sons, Chipping Norton, UK.

ICZN (1999). International Code of Zoological Nomenclature. 4th edition. The International Trust for Zoological Nomenclature, London.

McWhae, J.R.H., Playford, P.E., Lindner, A.W., Glenister, B.F. and Balme, B.E. (1958). The Stratigraphy of Western Australia. Melbourne University Press, Melbourne.
Reid, A.L. (1996). Review of the Peripatopsidae (Onychophora) in Australia, with comments on peripatopsid relationships. Invertebrate Taxonomy 10(4): $1-936$.

Ruhberg, H. (1985). Die Peripatopsidae (Onychophora) Systematik, Ökologie, Chorologie und phylogenetische Aspekte. Zoologica 137: 1-184.

Spencer, B. (1909). Description of a new species of Peripatoides from West Australia. Royal Society of Victoria, Proceedings 21(2): 420-422.

Tait, N.N., Stutchbury, R.J. and Briscoe, D.A. (1990). Review of the discovery and identification of Onychophora in Australia. Linnean Society of New South Wales, Proceedings 112(2): 153-171.

Van Der Lande, V. (1978). The occurrence, culture and reproduction of Peripatoides gilesii Spencer (Onychophora) on the Swan Coastal Plain. The Western Australian Naturalist 14(2): 29-35.

Manuscript received 18 June 2001; accepted 6 November 2001. 
Kumbadjena, gen. nov. collection sites

Representatives of this genus have been collected at the following sites. Further work, including the examination of an additional suite of characters (perhaps molecular and/or karyology) will be necessary before specimens from these localities can reliably be assigned to species. Specimen lots are listed geographically from west to east. Figure 8 shows the distribution of members of this genus. Alt. = altitude.

\begin{tabular}{|c|c|c|c|c|c|c|c|c|}
\hline No and sex & Locality & Latitude & Longitude & Alt. & Date & Collector(s) & Depository & Habitat \\
\hline $2 \delta, 29$ & $\begin{array}{l}\text { Leeuwin Naturaliste NP, Boranup Karri Forest } \\
\text { Scenic Drive, } 13.9 \mathrm{~km} \text { north of intersection of } \\
\text { Caves Rd and Forest Grove Rd }\end{array}$ & $34^{\circ} 06^{\prime} \mathrm{S}$ & $115^{\circ} 03^{\prime} \mathrm{E}$ & $80 \mathrm{~m}$ & 5 Apr 2000 & $\begin{array}{l}\text { A. Reid \& } \\
\text { R. Roberts }\end{array}$ & WAM T42561 & in logs \\
\hline $5 \delta, 79$ & $"$ & $"$ & $"$ & $"$ & 4 Apr 2000 & $"$ & WAM T42562 & $"$ \\
\hline 19 & Nindup, W of Witchcliffe & $34^{\circ} 03^{\prime} \mathrm{S}$ & $115^{\circ} 03^{\prime} \mathrm{E}$ & & 6 Feb 1993 & J. M. Waldock & WAM 95/489 & \\
\hline 1 juv. & $\begin{array}{l}\text { Witchcliffe area, cave WL112 (Labour Cave), } \\
3 \mathrm{~m} \text { from bottom of entrance hole }\end{array}$ & & & & 9 Apr 1994 & R. Foulds & WAM $95 / 512$ & \\
\hline 19,3 juv. & near Devils Lair Cave & $34^{\circ} 08^{\prime} \mathrm{S}$ & $115^{\circ} 08^{\prime} \mathrm{E}$ & $100 \mathrm{~m}$ & 14 May 1995 & A. Reid & WAM T42563 & under $\log$ \\
\hline 19 & $\begin{array}{l}\text { Augusta, E side of estuary (from well on } \\
\text { property of } N \text {. Ellis) }\end{array}$ & $-34^{\circ} 20^{\prime} \mathrm{S}$ & $115^{\circ} 09^{\prime} \mathrm{E}$ & & 12 Oct 1980 & $\begin{array}{l}\text { S. Slack-Smith \& } \\
\text { M. Ellis }\end{array}$ & WAM $89 / 384$ & \\
\hline 19 & $2 \mathrm{~km} \mathrm{SW}$ of Margaret River & $33^{\circ} 57^{\prime} \mathrm{S}$ & $115^{\circ} 24^{\prime} \mathrm{E}$ & & 4 Jan 1992 & J. M. Waldock & WAM $95 / 486$ & \\
\hline 19 & Karri Valley Resort & $34^{\circ} 26^{\prime} \mathrm{S}$ & $115^{\circ} 51^{\prime} \mathrm{E}$ & & 21 Oct 1997 & J. M. Waldock & WAM T40859 & karri litter \\
\hline 10,29 & Pemberton, forest opposite Youth Hostel & $\sim 34^{\circ} 24^{\prime} \mathrm{S}$ & $115^{\circ} 58^{\prime} \mathrm{E}$ & & 20 May 1995 & A. Reid & WAM T42564 & in $\log$ \\
\hline 1 juv. & Treen SF & & & & 17 May 1995 & A. Reid & WAM T42565 & in $\log$ \\
\hline 19 & Pemberton Youth Hostel & $34^{\circ} 24^{\prime} \mathrm{S}$ & $115^{\circ} 58^{\prime} \mathrm{E}$ & & 2 May 1992 & $\begin{array}{l}\text { M. S. Harvey \& } \\
\text { J. M. Waldock }\end{array}$ & WAM $91 / 1133$ & \\
\hline 19 & Pemberton, East Brook & $\sim 34^{\circ} 24^{\prime} S$ & $115^{\circ} 58^{\prime} \mathrm{E}$ & & 22 Aug 1956 & B. Y. Main & WAM $89 / 1125$ & Casuarina bark \\
\hline 29 & Pemberton HL 62, Big Brook 12 & $\sim 34^{\circ} 24^{\prime} \mathrm{S}$ & $116^{\circ} 00^{\prime} \mathrm{E}$ & & 15 Nov 1971 & J. A. Springett & WAM 76/8-9 & \\
\hline $90,89,2$ juv. & Big Brooke SF, near Pemberton & $34^{\circ} 24^{\prime} \mathrm{S}$ & $116^{\circ} 00^{\prime} \mathrm{E}$ & $150 \mathrm{~m}$ & 6 Apr 2000 & $\begin{array}{l}\text { A. Reid \& } \\
\text { R. Roberts }\end{array}$ & WAM T42566 & in logs \\
\hline 10.19 & Bombakup SF, creek line & $34^{\circ} 36.5 \mathrm{~S}$ & $116^{\circ} 01.9^{\prime} \mathrm{E}$ & & 28 Jan 1999 & S. L. Judd & WAM T40855 & $\begin{array}{l}\text { dense litter at } \\
\text { base of karri }\end{array}$ \\
\hline 19 & Bombakup SF, creek line & $34^{\circ} 36.5^{\prime} \mathrm{S}$ & $116^{\circ} 01.9^{\prime} \mathrm{E}$ & & 28 Jan 1999 & S. L. Judd & WAM T40854 & $"$ \\
\hline 19 & Preston Conservation Park & $33^{\circ} 36.2^{\prime} \mathrm{S}$ & $116^{\circ} 03.8^{\prime} \mathrm{E}$ & & 24 Nov 1998 & S. L. Judd & WAM T40862 & $\begin{array}{l}\text { hand collected } \\
\text { in old growth } \\
\text { jarrah }\end{array}$ \\
\hline $7 \delta, 3 q, 1$ juv. & Mt Chudalup, $15.7 \mathrm{~km} \mathrm{~S}$ of Northcliffe & $34^{\circ} 46^{\prime} \mathrm{S}$ & $116^{\circ} 05^{\prime} \mathrm{E}$ & $100 \mathrm{~m}$ & 7 Apr 2000 & $\begin{array}{l}\text { A. Reid \& } \\
\text { R. Roberts }\end{array}$ & WAM T42567 & in logs \\
\hline 18 & Mt Chudalup & $34^{\circ} 46^{\prime} \mathrm{S}$ & $116^{\circ} 05^{\prime} \mathrm{E}$ & & 3 Sep 1990 & $\begin{array}{l}\text { G. Wardell \& } \\
\text { Johnston }\end{array}$ & WAM $90 / 1723$ & \\
\hline 19 & Walpole Nornalup NP & $34^{\circ} 54^{\prime} \mathrm{S}$ & $116^{\circ} 29^{\prime} \mathrm{E}$ & & 9 Apr 2000 & $\begin{array}{l}\text { A. Reid \& } \\
\text { R. Roberts }\end{array}$ & WAM T42568 & in $\log$ \\
\hline
\end{tabular}


$10,19,1$ juv. Walpole Nornalup NP, Conspicuous Beach Rd, $2.9 \mathrm{~km} \mathrm{~S}$ of South Coast Hwy

$10,29 \quad$ Walpole Nornalup NP, Broke Inlet, beside Broke Inlet $\mathrm{Rd}, 7 \mathrm{~km}$ from intersection with

South Western Hwy

$18 \quad$ Long Thompson Forest Block

$1 \%$ Mt Frankland NP

$1 \delta^{*}$

16,19

19

Mt Frankland NP, Crossing Block

Rate Forest Block

$23 \mathrm{~km}$ east of Denmark, Tennessee South Rd

$10^{\circ}$

$50,4 \%, 2$ juv. William Bay NP, beside Byleveld's Lake

$30^{\circ}, 69,2$ juv. West Cape Howe NP, $1.6 \mathrm{~km}$ S of intersection of Coombes Rd and Shelley Beach Rd, $0.4 \mathrm{~km}$ inside NP entrance

\begin{tabular}{|c|c|c|c|c|c|c|}
\hline $34^{\circ} 54^{\prime} \mathrm{S}$ & $116^{\circ} 29^{\prime} \mathrm{E}$ & $70 \mathrm{~m}$ & 10 Apr 2000 & $\begin{array}{l}\text { A. Reid \& } \\
\text { R. Roberts }\end{array}$ & WAM T42570 & in logs \\
\hline $34^{\circ} 39.6 \mathrm{~S}$ & $116^{\circ} 42.2^{\prime} \mathrm{E}$ & & 11 Jan 1999 & S. L. Judd & WAM T40860 & \\
\hline $34^{\circ} 39^{\prime} \mathrm{S}$ & $116^{\circ} 49^{\prime} \mathrm{E}$ & $100 \mathrm{~m}$ & 9 Apr 2000 & $\begin{array}{l}\text { A. Reid \& } \\
\text { R. Roberts }\end{array}$ & WAM T42571 & in $\log$ \\
\hline $34^{\circ} 48.2^{\prime} \mathrm{S}$ & $116^{\circ} 53.0^{\prime} \mathrm{E}$ & & $10 \operatorname{Jan} 1999$ & S. L. Judd & WAM T40861 & \\
\hline $34^{\circ} 50^{\prime} \mathrm{S}$ & $117^{\circ} 00.4^{\prime} \mathrm{E}$ & & $9 \operatorname{Jan} 1999$ & S. L. Judd & WAM T40863 & \\
\hline$\sim 34^{\circ} 57^{\prime} \mathrm{S}$ & $117^{\circ} 21^{\prime} \mathrm{E}$ & & 8 Dec 1974 & P. Smith & WAM $89 / 383$ & $\begin{array}{l}\text { in shade at } \\
\text { base of tree }\end{array}$ \\
\hline$"$ & $"$ & & 22 May 1995 & A. Reid & WAM T42572 & under log \\
\hline $35^{\circ} 00^{\prime} \mathrm{S}$ & $117^{\circ} 13^{\prime} \mathrm{E}$ & $40 \mathrm{~m}$ & 17 Apr 2000 & $\begin{array}{l}\text { A. Reid \& } \\
\text { R. Roberts }\end{array}$ & WAM T42573 & $\begin{array}{l}\text { in and } \\
\text { under logs }\end{array}$ \\
\hline $35^{\circ} 05^{\prime} \mathrm{S}$ & $117^{\circ} 38^{\prime} \mathrm{E}$ & $150 \mathrm{~m}$ & $\begin{array}{l}13-14 \text { Apr } \\
2000\end{array}$ & $\begin{array}{l}\text { A. Reid \& } \\
\text { R. Roberts }\end{array}$ & WAM T42574 & in $\log$ \\
\hline$\sim 35^{\circ} 05^{\prime} S$ & $117^{\circ} 38^{\prime} \mathrm{E}$ & & 27 Mar 1993 & $\begin{array}{l}\text { M. S. Harvey \& } \\
\text { J. M. Waldocck }\end{array}$ & WAM 95/511 & karri litter \\
\hline$\sim 35^{\circ} 05^{\prime} \mathrm{S}$ & $117^{\circ} 38^{\prime} \mathrm{E}$ & & & B. Y. Main & WAM 91/1126 & karri litter \\
\hline $35^{\circ} 05^{\prime} \mathrm{S}$ & $117^{\circ} 54^{\prime} \mathrm{E}$ & & 26 Mar 1993 & $\begin{array}{l}\text { M.S. Harvey \& } \\
\text { J. M. Waldock }\end{array}$ & WAM $95 / 498$ & \\
\hline$"$ & $"$ & & $"$ & $"$ & WAM $95 / 508-10$ & litter \\
\hline $34^{\circ} 23^{\prime} 17^{\prime \prime S}$ & $118^{\circ} 10^{\prime} 18^{\prime \prime} \mathrm{E}$ & & $\begin{array}{l}27 \text { May-17 } \\
\text { Dec } 1996\end{array}$ & $\begin{array}{l}\text { M. S. Harvey, J. } \\
\text { M. Waldock \& } \\
\text { B. Y. Main }\end{array}$ & WAM $99 / 245$ & \\
\hline$\sim 34^{\circ} 57^{\prime} \mathrm{S}$ & $118^{\circ} 11^{\prime} \mathrm{E}$ & & 22 May 1970 & J. A. Springett & WAM 76/4-5 & \\
\hline
\end{tabular}

West Cape Howe NP, S of Torbay Hill nr Sth Rd

Torbay Head, Lot 40 adjacent to West

10,1 juv. gully outside $N$ edge of Torndirrup NP

on Limeburners Rd

Stirling Range NP, Wedge Hill

$10^{*}, 29$

19

Two People's Bay
Cape Howe NP

9 Apr $2000 \quad$ A. Reid \&

R. Roberts

in logs 